This document is the accepted manuscript version of the following article:

Moza, M. I., Postolache, C., Benedek, A. M., Moldoveanu, M., \& Spaak, P. (2021).

Geographical and temporal patterns of cyanobacterial assemblages in the Danube Delta lake

complexes. Hydrobiologia, 848, 753-771. https://doi .org/10.1007/s10750-020-04466-w

1

Geographical and temporal patterns of cyanobacterial assemblages in the Danube Delta 2

3

\title{
lake complexes
}

4 Maria Iasmina Moza ${ }^{1,2, *}$, Carmen Postolache ${ }^{1,3,{ }^{*}, \text { Ana Maria Benedek }}{ }^{4}$, Mirela Moldoveanu ${ }^{5}$, $5 \quad$ Piet $\operatorname{Spaak}^{6}$

6

$7 \quad{ }^{1}$ Faculty of Biology, University of Bucharest, Department of Systems Ecology and

8 Sustainable Development, Doctoral School in Ecology, Bucharest, Romania

$9 \quad{ }^{2}$ Foundation Conservation Carpathia - FCC, Wildlife Genetic Monitoring Laboratory,

10 Brasov, Romania

$11{ }^{3}$ Research Institute of the University of Bucharest - ICUB, Bucharest, Romania

$12{ }^{4}$ Faculty of Science, "Lucian Blaga" University, Applied Ecology Research Center, Sibiu,

13 Romania

$14{ }^{5}$ Institute of Biology Bucharest, Department of Ecology, Taxonomy and Nature

15 Conservation, Romanian Academy, Bucharest, Romania

$16{ }^{6}$ Swiss Institute for Environmental Science and Technology (Eawag), Dübendorf,

17 Switzerland

$19 *$ *uthors share the first authorship, they had equal contribution

21 Correspondence 1: Maria Iasmina Moza, Foundation Conservation Carpathia, Wildlife

22 Genetic Monitoring Laboratory, Calea Feldioarei 27, 500450, Brasov, Romania

23 Tel.: +40 743620132

24 E-mail: iasmina_moza@yahoo.com 
26 Correspondence 2: Ana Maria Benedek, Faculty of Science, "Lucian Blaga" University,

27 Applied Ecology Research Center, 5-7 Raţiu Street, 550012 Sibiu, Romania.

$28 \quad$ Tel.: +40744538278

29 E-mail: benedek_ana@yahoo.com

30

31 Conflict of interests: the authors declare that they have no conflict of interests 


\section{Abstract}

34 Danube Delta shallow lakes experience cyanobacteria blooms that can negatively affect the aquatic ecosystem. Although there are several studies on Danube Delta cyanobacteria, little is known about their spatial-temporal patterns and the potential predictive role they can offer.

37 We therefore analyzed the distribution of cyanobacteria in 19 lakes belonging to three lake complexes, and tested whether their seasonal dynamics are in line with the predictions of the PEG model. Furthermore, we investigated to which extent cyanobacteria diversity and abundance were related to lake hydrogeomorphological characteristics such as: surface, water level, connectivity, water retention, flood risk, transparency. Although lakes had different seasonal cyanobacterial assemblages, the biovolume and genus richness had a geographical pattern, decreasing from south-east (lakes forming the fluvial delta) towards north-west (lakes forming the maritime delta). Cyanobacteria biovolume reflected largely the PEG model peaking in summer (the fluvial delta) and autumn ( the maritime delta). Genus richness followed the same pattern. Cyanobacteria distribution was predicted by various abiotic (e.g.

47 risk of flooding, connectivity) and biotic factors (e.g. submersed macrophytes, phytoplankton

48 diversity, peat deposits). Our study contributes to the understanding of cyanobacteria diversity and distribution in shallow interconnected lakes by revealing the complexity of predictors for geographical and seasonal patterns.

52 Key words: freshwater cyanobacteria, RDA, assemblage, shallow lakes, spatial-temporal dynamics, hydrogeomorphological predictors 


\section{Acknowledgements}

56 This work was supported by the Swiss Enlargement Contribution, project IZERZ0 142165,

57 "CyanoArchive", in the framework of the Romanian-Swiss Research Programme. The

58 authors express their thanks to (chronologically): Cristina Sandu for making this project

59 possible, Francesco Pomati for all the help and supervising, Ioana Enache, Doru Simon

60 Dobre, Aurel Damian, Vanea Dunaev ${ }^{\dagger}$, Laura Parpală, Emilia Radu, Ciprian Bîrsan and

61 Laurențiu Butâlchin, the technicians Stela Sofa, Esther Keller and Regula Illi, and Christoph

62 Tellenbach for the taxonomy update. Many thanks to Liliana Torök, Geta Rîșnoveanu and

63 Angela Curtean-Bănăduc for their useful comments and observations, Larisa Florescu and

64 Darmina Niţă for answering the questions related to this subject, Iulia Nichersu and Ioan

65 Păceșilă for providing the values of the lake surfaces, Flo Botez for the partial text correction and Eugenia Cioacă for all the help in providing references. All our gratitude goes to Ioan

67 Sîrbu for his assistance with the statistics, essential guidance and constant support and to

68 Daniel Roelke, Adrian Florea and Janne Soininen for all the useful suggestions after

69 reviewing the manuscript. Special thanks go to Laura Kuhlmann for the language editing, to

70 the Editor and two anonymous Reviewers for their comments that substantially improved the 71 manuscript. 
Introduction

74 Deltas support high biodiversity and supply many ecosystem services (Russi et al., 2013).

75 Water quantity and quantity, as well as delta's biodiversity is affected by multiple use of these ecosystems by many stakeholders (Erwin, 2009). Biodiversity is used for monitoring the ecological state of environments ( $\underline{\text { Guerold, 2000; }}$ Schmitz \& Nagel, 1995). Biodiversity decreases with environment degradation (Botnariuc \& Vădineanu, 1982; Cardinale et al., 2012), and is therefore a key measure of environmental quality in lake ecosystems (Sayer et al., 1999). The study of biodiversity in river deltas from temperate regions and in their associated human impacted lakes is of great importance (Botnariuc \& Vădineanu, 1982;

Kallis \& Butler, 2001; Penning et al., 2008).

The Danube Delta, shared by Romania (80\% of its surface) and Ukraine (20\%), is a large and complex hydrological system through which water flows in three main branches (Chilia, Sulina and Sf. Gheorghe) and consist of hundreds of shallow lakes, connecting channels and floating reed beds (Coops et al., 2008; Găldean \& Ruști, 2006). At present, the Danube Delta represents one of the most valuable European natural wetlands. The mixture of several types of natural, partly modified, or man-made ecosystems (Gâstescu et al., 1999), hosts over 1615 plant species and 3491 invertebrate and vertebrate species (Oosterberg et al., $\underline{2000}$ ), thus representing a global biodiversity hotspot (Giosan, 2014). It is characterized by a greater biodiversity compared to other European deltas due to its high habitat heterogeneity (Buijse et al. 2002). Unfortunately, the anthropic pressure, consisting of hydrotechnological interventions along the main Sulina branch between 1947 and 1989, led to significant changes in the water regime of the Danube Delta's natural hydrological network (Irimus, 2006). The hydrological regime is strongly influenced by temporal water fluctuations due to weather events in the catchment (e.g. snow melt or high precipitations). This influx is

97 subsequently returned to the adjacent secondary channels during summertime, having 
ecological consequences in lakes. The Danube Delta comprises two sectors: a fluvial and a maritime one. The first sector includes the older lakes developed within the former gulf of the

100 Danube river, with smaller and deeper lacustrine areas, partly subjected to an intensive

101 siltation process. The second sector includes one of the most important lacustrine complex

102 (Roșu-Puiu) affected by major morphohydrographic changes in the contact zone with the

103 Black Sea (Oosterberg et al., 2000). Here also the last and most influencing dredging works were done (Romanescu, 1999). The maritime delta is composed of lagoons and sandy barriers created by long shore circulation (Vespremeanu-Stroe et al., 2017).

107 organic pollution that occurred throughout the Danube River Drainage Basin and altered the aquatic ecosystems (Postolache et al., 2006; Vădineanu et al., 2001). As nutrient concentrations increased the dominance and abundance of phytoplankton, particularly cyanobacteria, also increases, often resulting in dense blooms, especially during summer

111 (Reynolds, 1984). Cyanobacteria can provide several ecological services (Díez \& Ininbergs,

112 2014). They fix nitrogen and release oxygen by photosynthesis, accumulate phosphorus and 113 reflect the ecological state of the environment (i.e. bioindicator) (Chaurasia, 2015; Mateo et

114 al., 2015). But when cyanobacteria blooms occur, they are usually toxic and have severe consequences (release of toxins, organic material enrichment in sediment, negative impact on

116 the food web and increased bacterial activity) for the entire ecosystem (

117 particular, algal blooms alter ecological services, such as water oxygenation and quality of

118 drinking water. These problems seem to accentuate as a result of climate change (Kleinteich

119 et al., 2012; Paerl \& Huisman, 2008; Paerl \& Huisman, 2009).

The spatial distribution of cyanobacteria taxa may depend on environmental conditions such as: climatic gradients and structural characteristics of the landscape (e.g. the

122 presence or absence of lake vegetation) (Stoch et al., 2016). The hydrology of the Danube 
123 Delta lakes is complex and the lakes are not isolated, but are parts of a large riverine system

124 (Oosterberg et al., 2000). Therefore, connectivity and hydrogeomorphological features should

125 also be taken into account when studying cyanobacteria distribution in the Danube Delta

126 lakes. Water level can be used as a proxy for the hydrological regime (Irimus, 2006) since

127 water enters the lakes from the main channels into the secondary canals during spring with

128 the rising of the water level and exits the lakes during summer dry season, when water level 129 drops.

130 The Danube Delta is dominated by "flooded reed" (lakes with reduced exchange of 131 water and partially covered with floating vegetation), "floating reed beds" (near the lakes

132 with reduced exchange of water) and "lakes with large surface" or active change of water

133 (Năstase \& Năvodaru, 2008). The phytoplankton also plays an important role in the Danube

134 Delta since it can cause rapid turbidity changes in shallow lakes by the water input from the main channels as revealed also by its spatial distribution observed on satellite images (Güttler

136 et al., 2013). In contrast, macrophytes have an essential role in the maintenance of low

137 turbidity (Vădineanu et al., 1992) and compete with the phytoplankton for nutrients. Previous

138 studies investigated targeted some major aspects of the Danube Delta's ecosystems, such as

139 the impact of eutrophication and the consequent changes that occur in the Delta's structure

140 and functions (Postolache, 2003, 2006). Additionally, several publications describe

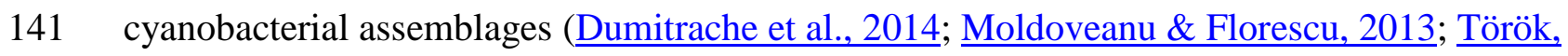

$142 \underline{2008 b}$ ) indicating that bloom forming species, such as Microcystis aeruginosa (Kützing)

143 Kützing 1846 or Aphanizomenon flos-aquae Ralfs ex Bornet \& Flahault 1886, were

144 frequently found in the shallow eutrophic lakes of the Danube Delta (Moldoveanu \&

145 Florescu, 2013; Török, 2008b).

146 The seasonal succession of phytoplankton in temperate (deep) lakes has been

147 described with the PEG (Plankton Ecology Group) model (De Senerpont Domis et al., 2013). 
148 In this model, two peaks of biomass occur: one in spring, involving small edible algae, and

149 the other in summer, involving large or colonial algae resistant to zooplankton grazing.

150 Phytoplankton dynamics in the Danube Delta are not fundamentally different from that in

151 other temperate lakes. According to the PEG model, in the Danube Delta we might expect a

152 high nutrients input during spring that can lead to diatoms blooms. This is followed by a clear

153 water phase with a high grazer pressure and low nutrients availability and a shift to

154 cyanobacteria in summer. Ultimately, increased water mixing, nutrient availability and

155 predominance of filamentous algae and blooms are common in autumn (Oosterberg et al.,

156 2000) (Ibellings, 1992).

157 Anthropogenic interventions have an important role in driving the seasonal variation

158 of phytoplankton as well. Therefore, disturbances caused by changes in the external

159 environment (e.g. pollution, nutrients), affect diversity (Sommer et al., 1986), which is an

160 important aspect of community structure (Xiao et al., 2011). Anthropogenic-caused

161 disturbances can alter cyanobacterial seasonality especially in those areas where the highest

162 cyanobacteria biomass and diversity is observed (such as the Roşu-Puiu lake complex)

163 (Moldoveanu \& Florescu, 2013).

164 In this study, we analyzed the geographical distribution and seasonal dynamics of

165 cyanobacteria in the Danube Delta lake complexes over a two-year period. Our study aims to

166 test the following hypotheses: H (1) cyanobacterial assemblages differ among lake complexes

167 with respect to biovolume and richness, being more dominant in the maritime delta, $\mathrm{H} \mathrm{(2)}$

168 there is significant seasonal variation of cyanobacterial assemblages according to PEG model

169 and H (3) cyanobacterial assemblages are influenced by the hydrogeomorphological

170 characteristics that distinguish the Danube Delta lake complexes.

172 Material and methods 
173 Study area and sampling

174 The Danube Delta is a Biosphere Reserve located at $45^{\circ} 0^{\prime} \mathrm{N}$ latitude and $29^{\circ} 0^{\prime} \mathrm{E}$ longitude in

175 the eastern part of Romania. It comprises more than 300 water bodies, mainly shallow lakes,

176 grouped in lake complexes, and interconnected by river branches and man-made canals

177 (Coops et al., 2008; Romanescu, 2005). The four major lake complexes (LCs) in the Danube

178 Delta, are named after the two most representative lakes of each complex (Oosterberg et al.,

179 2000). Listed from oldest to youngest, these are Șontea-Furtuna (LC1), Isac-Gorgova (LC2),

180 Matița-Merhei (LC3) and Roșu-Puiu (LC4). The first three complexes belong to the fluvial

181 delta and the fourth one to the maritime delta, being separated by the Caraorman sand dune

182 and forest. Lakes in the most upstream complex Sontea-Furtuna have consistently low

183 residence times, higher transparency and very good connection to the main branch. These

184 lakes have therefore a high flooding risk. In the Matița-Merhei and Isac-Gorgova complex we

185 find isolated lakes with a high residence time, organic bottom and high macrophyte coverage

186 and phytoplankton diversity. In Roșu-Puiu on the other hand, the residence time in the large

187 lakes is low, but increases in the small lakes (see Table S4 for more details) (Friedrich et al.,

188 2003; Gâștescu \& Știucă, 2008; Oosterberg et al., 2000).

189 In the current study, 19 shallow lakes situated on both sides of the Sulina branch and

190 belonging to complexes 2-4 were sampled (Fig. 1). The locations of the studied lakes and a

191 brief characterization of the lake complexes are given in Table 1. The lakes' limnological

192 description was already detailed in previous papers (Enache et al., 2019; Fontana et al.,

193 2018). Sampling campaigns were carried out seasonally (except winter) for two years, in

1942013 and 2014, in spring (May), summer (July) and autumn, (September/October), resulting

195 in 114 phytoplankton samples.

196 
Cyanobacteria analysis

198 Water samples were taken from the entire water column, from the center of each lake, using a

199 Schindler - Patalas device (5 L). We extracted one sample (5 L) from the middle of the water

200 column from lakes less than one meter deep, two samples (a "deep" and "less deep one": 10

201 L) from lakes with a depth between one and two meters and three samples, one from each

202 "meter layer" (15 L), from lakes deeper than two meters. From the final volume of mixed

203 water a sample of $500 \mathrm{~mL}$ was taken, stored in a plastic container and fixed in the field with

$2044 \%$ formaldehyde.

205

In the laboratory, the phytoplankton samples were concentrated to $100 \mathrm{~mL}$, by

sedimentation for a few days, prior to cyanobacteria taxonomical identification at species level using specific keys (ㅂuber-Pestalozzi, 1938; Komárek, 1998; Komárek et al., 1998;

Komárek \& Anagnostidis, 2005; Komárek et al., 2014).

Cyanobacteria total abundance, expressed as cells $\mathrm{L}^{-1}$ (used for biovolume calculation), was estimated through direct count with a Zeiss inverted microscope using the

211 Utermöhl technique (Utermöhl, 1958). Cyanobacteria total biovolume, expressed as $\mu \mathrm{m}^{3} \mathrm{~L}^{-1}$,

212 was determined according to a protocol described in (Fontana et al., 2018) based on a mean cell biovolume (calculated from geometric approximation of each species/genera cell shapes)

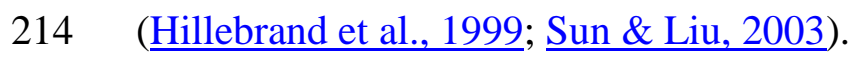

215 The final value used for statistical analyses was divided by $10^{6}$, expressed as cubic

216 micrometer per microliter $\left(\mu \mathrm{m}^{3} \mu \mathrm{L}^{-1}\right)$ and was subsequently log-transformed (using natural

217 logarithm) for normalization of the residuals in the univariate models and to evaluate

218 relationships between response and explanatory variables on a multiplicative instead of an

219 additive scale.

220 Identification of some cyanobacteria was not possible at species level, therefore some species 221 are listed as "sp." (Table S1). Thus, statistical analyses (using biovolume and richness) were 
performed at the genus level, as it was done previously by Coops and his colleagues (Coops

et al., 2008). For each of the hypotheses we considered three aspects of the cyanobacterial

biovolume of each genus in the assemblage) - each giving a different insight into the mechanisms of their spatio-temporal patterns.

Environmental variables

The assessment of the hydrogeomorphological variables (Table S4) and estimation of aquatic macrophytes were done as follows: (1) water level (depth) and transparency were measured in the center of the lake using a Secchi disk; this was done prior to water sampling in order to estimate how many Schindler-Patalas should be collected to cover the entire water column, (2) turbidity was measured with Hanna HI98713 turbidimeter, (3) water flow and water velocity were measured using a stream standard flow meter flow (MFP51 model from Geopacks), (4) surface, shore, main channel distance to lakes, elevation were measured using GoogleEarth Pro software and (5) macrophytes coverage was assessed based on photographs of the entire area of the lakes for total macrophytes and in situ directly from the boat based on direct visual observations of the floating and the submerged vegetation. For each lake and sampling campaign coverage was assigned to one of the following categories: low (0-25\%), medium (25-50\%) or high (50-100\%) (Radu et al., 2017). The analyses were performed using

241 the coverage mid-values of the three ranges $(12.5,37.5$ and $75 \%$ ) (Lauridsen et al., 2015) for

242 each sampling campaign and the average values were used for statistical analyses. Water retention (or residence) time was provided by a one-dimensional flow model (SOBEK)

244 (Oosterberg et al., 2000). SOBEK represents a dedicated hydrodynamic mathematical model

245 for Danube Delta water circulation based on measurements made in 1996 (Bondar \& Panin,

246 2001; Friedrich et al., 2003). Based on the modelling results, the residence time appears to be 
247 rather insensitive to seasonal water level fluctuations, even if the lakes within one complex can vary considerably in residence time (Oosterberg et al., 2000).

$250 \quad$ Statistical analyses

251 As response variables we included (1) biovolume, (used as a proxy for biomass (Passy \&

252 Legendre, 2006)), (2) genus richness (the number of genera identified in each sample), as a measure of cyanobacteria alpha diversity) and (3) genus composition (biovolume of individual genera). As predictors we considered the lake complex, season, year, and the environmental variables (hydrogeomorphological and vegetation characteristics) of the lakes.

256 Correlation was tested between the genus richness and biovolume, and between

257 environmental variables. We used Shapiro-Wilk test to verify the normality assumption of parametric tests and linear mixed models. No significant deviation from the normal distribution was detected for the residuals of linear mixed models. In contrast, vegetation and hydrogeomorphological variables as well as genus biovolume and richness were not normally distributed. Univariate analyses were performed with $\mathrm{R}$ version 3.5.1 (*R Core Team 2018).

262 For the mixed models we used „nlme” version 3.1-137 (Pinheiro et al., 2018). Multivariate analyses were performed with Canoco 5 (Ter Braak \& Šmilauer, 2012).

For each of the hypothesis we considered all three characteristics of the cyanobacterial assemblage: total biovolume, genus richness and composition. Each characteristic offered a different insight into the mechanisms affecting cyabobacterial spatiotemporal patterns. While patterns of the total biovolume and genus composition can be tested using univariate methods (i.e. including only one response variable and one or more predictors), testing of patterns in genus composition needs a multivariate approach. This is the reason why for each hypothesis we used both mixed models and RDA. Mixed models

271 were used instead of PERMANOVA because they are more general and may include as 
predictors both factors and continuous variables. As a parametric method, mixed models are

273

274

275

276

277

278

279

280

281

282

283

284

285

286

287

288

289

290

291

292

293

294

295

296 usually more powerful. To test the spatial-temporal patterns of cyanobacteria biovolume and genus richness $(\mathrm{H}(1)$ and $\mathrm{H}(2))$ we included lake complex, season and year, as well as their interaction, in a linear mixed model, considering lake as a random effect. For the comparison of mixed models, we used the likelihood ratio test (LR test). In addition, we tested the effect of space (lake complex) and time (season and year) on the biovolume in a redundancy analysis (RDA). We chose this linear ordination method over the unimodal method (canonical correspondence analysis, CCA) because in linear methods the raw abundance (biovolume) could be considered as response variable instead of relative abundance (standardized by sample total), and it includes also the empty samples. However, to apply linear ordination methods the genera turnover must be low (a gradient shorter than 4 units). Therefore, to shorten the gradient in our data we removed from the analysis 11 genera with less than 4 occurrences (Table S2). Significance of ordination axes was tested by the MonteCarlo permutation test with 999 permutations per test. The permutations were restricted

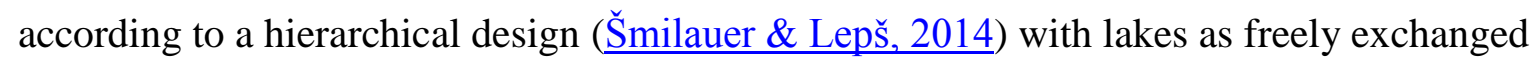
whole plots and time series permutations of split-plots dependent across whole-plots.

A comparison between constrained and unconstrained analysis was performed to analyze the overall variation in biovolume with the fraction of variation explained by space and time variables. We used the three-group variation partitioning procedure to assess and compare the explanatory importance of the lake complex and time (year and season).

Variation partitioning disentangles the unique and shared effects of two or more groups of explanatory variables representing distinct, interpretable phenomena, on the variation in the response data ( $\underline{\text { Šmilauer \& Lepš, 2014) }}$. Significance of individual genera to specific environmental variables was tested by means of t-value biplots ( To test the effect of the characteristics that define Danube Delta lake complexes on 
297 the biovolume and genus richness of cyanobacteria (H (3)), we first verified differences in

298 lake characteristics between lake complexes using the non-parametric Kruskal-Wallis test.

299 Among the 27 environmental variables described in our study (Table 1 and S4) eight were

300 collinear with the lake complex (e.g. delta type, formation age, water input), so they were not

301 used in the analyses. Spearman correlation was used to identify strongly correlated variables

302 and discard them from the predictors of biovolume and genus richness (Table S5 and S6). We

303 set the selection threshold at Spearman correlation coefficient $\rho=0.75$. Most correlations

304 were either not significant or weak, thus we removed only two variables from the analyses:

305 abundance of floating macrophytes (correlation between macroflo-macrotot: $\rho=0.95, p<$

306 0.001) and water flow (waterflow-watervelo: $\rho=0.98, \mathrm{p}<0.001$ ). Additonally, in the

307 univariate mixed models, multicolinearity of selected predictors was verified using the

308 variance inflation factor, and all values were lower than three, indicating no severe

309 multicolinearity in our models. Because turbidity and transparence may be both cause and

310 effect of cyanobacteria biovolume, we did not use them as predictors.

311 In the multivariate analyses, interactive forward selection was applied to choose a

312 parsimonious set of predictors for the RDA, using False discovery rate values to correct for

313 the Type I error inflation. Using a partial RDA with lake complex as covariate we also tested

314 the effect that vegetation and hydrogeomorphological lake characteristics had on biovolume

315 of cyanobacteria genera in addition to lake complex. Partial ordinations focus on the

316 influence of the variables of prime interest after having accounted for the effect of the

317 covariates (Ter Braak \& Šmilauer, 2012). In the partial RDA the permutations for Monte Carlo

318 test were restricted to blocks defined by the covariate.

$320 \quad$ Results

321 Spatio-temporal patterns of cyanobacterial assemblages 
The total biovolume of cyanobacteria assemblages showed a significant seasonality $(\mathrm{LR}=32.977, \mathrm{df}=93, \mathrm{p}<0.001)$ and variation between lake complexes $(\mathrm{LR}=25.180, \mathrm{df}=16$, $\mathrm{p}<0.001)$. The effects of the year and the interaction between season and lake complex were however not significant (Fig. 2). Mean estimated biovolume in LC2 lakes during spring was $5.108\left(\mu \mathrm{m}^{3} \mu \mathrm{L}^{-1}\right)$, and the estimated variance of the random intercept was 0.124 . From spring to summer, mean biovolume increased 16.46 times, and from spring to autumn 7.45 times. Mean biovolume in LC2 was 2.81 times lower than in LC3 and 48.94 times lower than in LC4 (Table S3). The total cyanobacteria biovolume was notably the highest in LC4 (especially in Mândra, Roșuleț, Roșu, Puiu and Erenciuc), followed by LC3 (in Rădăcinoasele and Bogdaproste) (Fig. S1 and S2). Spatio-temporal patterns explained $24.71 \%$ (21.23\% adjusted) of the variation in cyanobacteria biovolume (pseudo-F $=7.1, \mathrm{p}=0.001$ ). The variation in the cyanobacterial assemblages was dominated by one gradient, from spring to summer to autumn and from LC2 and LC3 to LC4. All the cyanobacteria genera showed an increase in this direction along the first ordination axis (Fig. 3). Changes from 2013 to 2014 were correlated with the second axis, which showed also the difference between summer and autumn. Along this axis, different genera decreased in biovolume from summer to autumn and increased from 2013 to 2014. Other genera had an opposite trend, while certain genera showed no temporal trend (Jaaginema, Aphanizomenon, Microcystis) (Fig. 3). The t-value biplots revealed that only Trichormus decreased significantly in biovolume from summer to autumn and no genus increased significantly from 2013 to 2014. Rhabdogloea, Wollea and Aphcanocapsa

344 biovolume decreased significantly from 2013 to 2014 and increased from summer to autumn, 345 while for Snowella and Merismopedia only the response to year was significant. The 346 comparison between the unconstrained and the constrained ordination axes revealed that the 
347 first constrained axis had a medium explanatory efficiency $(51.71 \%)$, being highly significant

348 (pseudo- $\mathrm{F}=5.8, \mathrm{p}=0.001)$, while the second axis had a low explanatory efficiency $(13.96 \%)$

349 and was not significant.

350 In the variation partitioning, lake complex counted for most part of the explained

351 variation in biovolume $(62 \%$, pseudo- $\mathrm{F}=11, \mathrm{p}=0.001)$, followed by season $(32.1 \%$, pseudo-

$352 \mathrm{~F}=5.7, \mathrm{p}=0.001)$; the effect of year was marginally significant. Because the design was

353 orthogonal and balanced, there was no overlap between these effects.

354 Genus richness

355 During our survey we found 48 species of Cyanobacteria belonging to 29 genera (Table S1),

356 and 11 cyanobacteria genera were represented by only one species. On average, we found 2.5

357 species per genus, but the variation was very high (from 1 to 6 species per genus). Only

358 Chrooccocus, Jaaginema, Merismopedia, Microcystis and Rhabdogloea were found in all the

359 studied lake complexes (even in all lakes), while some genera were specific for LC4:

360 Cylindrospermum (in Roșu) and Dolichospermum (in Puiu) (Table S2). Folowing the same

361 tendency as for biovolume, we found the highest genus richness in LC4, particularly in Roșu

362 (Fig. S1 and S2), in which we recorded 14 cyanobacteria genera during the entire study

363 period.

The cyanobacteria genus richness also displayed significant seasonality ( $\mathrm{LR}=58.742$,

$\mathrm{df}=86, \mathrm{p}<0.001)$ in adition to variation between lake complexes $(\mathrm{LR}=29.751, \mathrm{df}=16, \mathrm{p}<$ 0.001) and years $(\mathrm{LR}=18.246, \mathrm{df}=86, \mathrm{p}<0.001)$ (Fig. 4 and 5). Mean estimated number of genera in LC2 lakes during spring 2013 was 1.46, and the estimated variance of the random intercept was 0.601 . From spring to summer genus richness increased by 2.87 and from spring to autumn by 2.25. Related to the other LCs, in LC2 mean richness was by 0.5 lower than in LC3 and by 2.45 lower than in LC4. Genus richness decreased in 2014 by 0.42 compared with 2013. The interaction between season and lake complex $(\mathrm{LR}=13.257, \mathrm{df}=$ 
$86, \mathrm{p}=0.010)$ and interaction between season and year $(\mathrm{LR}=7.874, \mathrm{df}=86, \mathrm{p}=0.019)$ had additional significant effects on cyanobacteria genus richness. positively correlated with biovolume (Fig. S3). The strongest correlation was found in autumn $2013(\mathrm{~S}=100.15, \mathrm{df}=36, \mathrm{p}<0.001, \rho=0.912)$ and the weakest in spring $2014(\mathrm{~S}=$ $414.5, \mathrm{df}=36, \mathrm{p}=0.003, \rho=0.636)$. There was also a significant and strong correlation between the two response variables over the whole study period $(\mathrm{S}=44505, \mathrm{df}=112, \mathrm{p}<$ $0.001, \rho=0.819)$.

Environmental variables

382 1. Characteristics defining the Danube Delta lake complexes

There were significant differences among the lake complexes between the median values of shoreline length, water level and velocity, abundance of submerse macrophytes, water retention time and transparency (Table 2, S5 and S6). LC4 has lakes with the highest shore length, which means they have a high degree of meandering, even if they have a big surface and the highest water level (Fig. S4), different wave intensities and lakebed type (Table S4). LC4 comprise lakes with a medium time of water retention and flood risk, highest water velocity and low phytoplankton diversity but the lowest transparency even if the macrophyte coverage is considerable. LC3, has most of the lakes situated farthest from main Sulina branch, with different degrees of connectivity, the lowest water levels, therefore a low flood risk in most of the lakes, medium water velocities, the smallest water retention time but the highest transparency due to their high macrophyte coverage and phytoplankton diversity.

394 LC2 is the second oldest lake complex (after LC1, not included in this study). LC2 lakes are not so meandered, and they have the highest connectivity, since they are the closest to the main branch, exhibiting therefore a high flood risk. LC2 lakes have the highest phytoplankton 
397 diversity and macrophyte coverage, medium water level and transparency. Due to their very

398 good connectivity, LC2 lakes have medium water retention time. Phytoplankton diversity

399 was strongly and negatively correlated with lake surface (Table S5 and S6) in the case of the

400 LC4 lakes, the larger lakes from LC3 as well as Isac from LC2, all having low phytoplankton

401 diversity. Transparency was strongly and negatively correlated with the water level. LC4

402 lakes had the highest water level and less than 50\% transparency. The only exception was

403 Erenciuc lake, which was also closer to the main branch and had a higher degree of

404 connectivity (Table S4).

405

406 2. Predictors of cyanobacterial assemblages

407 Biovolume

408 In addition to season, some of the lake characteristics could be used as predictors of

409 cyanobacteria biovolume, $(\mathrm{LR}=34.97, \mathrm{df}=93, \mathrm{p}<0.001)$. Best model included: water level,

410 abundance of macrophytes, flooding risk and phytoplankton diversity (Table 2).

411 Cyanobacteria biovolume increased 6.96 times with the increase of water level by one meter

412 and 1.03 times with the increase of abundance of macrophytes by one category. The

413 biovolume decreased 2.35 times with the increase of risk of flooding from one category to

414 another, and 2.53 times with the increase in diversity of phytoplankton by one category.

415 In the RDA (Fig. S5) vegetation and hydromorphological characteristics explained

$41616.34 \%$ (13.27 adjusted) of the variation in cyanobacteria biovolume. The first constrained

417 axis (pseudo-F $=4.8, p=0.002$ ), given mainly by water level, negatively correlated with

418 flood risk, and to a lesser degree with abundance of macrophytes and diversity of

419 phytoplankton. Most genera (Johanseninema, Leptolyngbya, Aphanocapsa, Microcystis,

420 Trichoderma, Aphanizomenon, Jaaginema, Chroococcus, Planktolyngbya) showed a

421 significant positive response to water level. Few genera had a significant negative response to 

positively to macrophytes.

In the partial RDA (Fig. 6), when accounting for the variation explained by the lake complex, best predictors were: water velocity, peat deposits and flood risk. Their effect was significant (pseudo- $\mathrm{F}=2, \mathrm{p}=0.001$ ), but their additional explanatory power was low (only $5.17 \%, 2.54$ adjusted). Most genera were positively correlated along the first axis with the water velocity and peat deposits. Only Planktolyngbya had a significant response to peat deposits and both, Planktolyngbya and Merismopedia, had a significant response to water velocity. The negative response of Planktolyngbya to flood risk was also significant.

$\underline{\text { Genus richness }}$

In the univariate models, in addition to season $(\mathrm{LR}=63.494, \mathrm{p}<0.001)$ and year $(\mathrm{LR}=$ 19.536, $\mathrm{p}<0.001$ ), cyanobacteria genus richness was best predicted by surface, elevation, water level, water velocity, distance from the main channel and connectivity (Table 2). For example richness increased by 3.27 with the increase of water level by one meter, by 4.28 with the increase of water velocity with $0.1 \mathrm{~m} \mathrm{~s}^{-1}$ and decreased by 0.14 with the increase of distance from the main channel with one $\mathrm{km}$ and by 1.34 with the increase of connectivity by one category.

\section{Discussions}

442 Spatial distribution of cyanobacterial assemblages: Hypothesis 1

443 As hypothesized, the cyanobacterial assemblages of the studied lakes showed a

444 heterogeneous structure, with different richness and biovolume among lake complexes (LCs)

445 (Fig. 2-5). According to Bellinger and Sigee (Bellinger \& Sigee, 2010), this aspect is

446 characteristic of any delta floodplain with shallow lakes. 
448 included in 19 genera with toxic potential (Table S1 and S2). In an earlier study, (Cărăuș \&

449 Nicolescu, 2006) 1098 phytoplankton species were identified in the Danube Delta (> 400

450 lakes sampled between 1974-2000), containing 177 cyanobacteria species (17\%) belonging to

45134 genera. Our taxon list was shorter (48 out of 177) since we studied only 19 lakes over two

452 years. Nevertheless, our results confirm that the Danube Delta still presents a high diversity 453 of cyanobacteria.

All the genera were found in all lakes. Few genera were representative either for several lakes or for an entire LC, which highlight the Danube Delta ecosystems heterogeneity (Table S2). For example, Anabaenopsis, Cylindrospermopsis, Cylyndrospermum,

Dolichospermum and Aphanothece were observed only in LC4, confirming our hypothesis of higher richness in the maritime delta. However, comparing these findings with results available in the literature (Moldoveanu \& Florescu, 2013; Moldoveanu et al., 2015; Török, 2005a, 2005b, 2005c, 2007, 2008a, 2009b, 2011) we see that some species (e.g. Microcystis $s p$.) are reported constantly. We conclude that these lakes were under high ecological stress, as they were dominated by cyanobacteria species which indicate increased eutrophication (Kauppila et al., 1995).

Our study revealed an increasing density of cyanobacteria from the West to the East, along the flow direction of the main channel (Fig. 5). This observation supports H (1) which states that cyanobacterial assemblages differ among lake complexes with respect to

467 biovolume and richness, being more dominant in the maritime delta. Previous studies showed that between 2001 and 2007 few lakes experienced frequent cyanobacteria blooms (especially in summer and autumn) increasing in the same direction as we found: from LC2 to LC3 and LC4 (Török et al., 2008). This observation is similar to the biomass pattern that we found in our studied lakes (Fig. 2 and Table S3). We observed a synchrony between genus richness 
and biovolume distribution concentrated at the southern part of the Danube Delta, with the

473 highest recorded values throughout the study period in the Roșu-Puiu (LC4) (Fig. 2, 4, S1, S2 and Table S3). The lakes from Roșu-Puiu (LC4) were also more constant in terms of cyanobacteria abundance and genus compositions compared with the other two LCs. This was also reported in previous studies (Nicolescu, 1992), again supporting our hypothesis.

In comparison with LC4, lakes from LC3 present only episodic peaks of cyanobacteria, otherwise having low diversity and abundance (Fig. S2). An explanation could be that reed, well represented in LC3 (Table S4), inhibits cyanobacteria development, notably via phenols produced by aquatic macrophytes that have allopathic effects (Antilla et al., 2015; Watson, 2014; Zhou et al., 2004). The fluvial delta (Matiţa-Merhei and Gorgova-

Uzlina LCs) is rich in stable reed (Iordachi \& Van Assche, 2014). Our results therefore support the explanation that reed beds inhibit cyanobacteria development. The competition between cyanobacteria and macrophytes also exists in Danube Delta's shallow lakes (Pantea, 1993). This is why cyanobacteria's ability to float is a further advantage in their competition with other taxa (Török, 2005b). All these factors could explain high records of cyanobacteria in some lakes of LC3 (Fig. S2 and Table S2) for instance, which are nevertheless dominated by aquatics plants (Table S4). There is a clear longitudinal and latitudinal gradient of the cyanobacteria distribution (Fig. 5), with highest densities in its lower part, namely in LC4. This observation supporting H (1), since there are "significant differences between LCs, with LC4 being the most distinct among them".

Temporal distribution of cyanobacterial assemblages: Hypothesis 2

494 The PEG model predicts that cyanobacteria are predominant in summer-autumn, namely July and September (De Senerpont Domis et al., 2013) . Generally, the phytoplankton in the

496 Danube Delta is dominated in spring by diatoms and green algae, while the cyanobacteria 
tend to develop to higher densities in all LCs in summer (Enache et al., 2019). In spring the composition of the diatoms indicates a mesoeutrophic status of the lakes. The occurrence of Oscillatoria blooms is for instance, characteristic for hypertrophic lakes, suggests a seasonal

500 shift of the trophic status (Năstase, 2009). According to previous findings (Dumitrache et al., 501 2014), the most prevalent cyanobacteria genera in Roșu-Puiu (LC4) were Anabaena, Lyngbya and Oscillatoria in July, and Microcystis and Oscillatoria in September. According to our results, in LC2 most of the lakes reached their cyanobacteria biovolume peaks in summer, with the exception of lake Isac (spring). In LC3, six out of ten lakes had their peaks in summer, two in spring (Bogdaproste and Lung) and two in autumn (Matița and Merhei). In LC4 two lakes reached the peak in summer and three in autumn (Roșu, Mândra and Erenciuc)

507 (Table S3). Following the same pattern, genus richness was the highest in summer, as expected in LC4, and lowest in spring (Fig. 4 and Table S3). Overall, the lowest values of biovolume and richness were recorded in lakes from LC2, which is part of the fluvial delta and well connected to the main channel. Therefore, our findings reveal that cyanobacteria assembly varied strongly between seasons (Fig. 2 - 4), largely in concordance with the PEG model at lake level, but fully fitted within the model as mean values per LCs. This could be very nicely seen in the RDA (Fig. 3), where all the vectors representing cyanobacteria genera are grouped in summer and autumn. Previous algal blooms were also observed in June of each year in LC2 (Uzlina) as well as in LC4 (Roșu and Roșuleț) during a survey performed between 1996-1998 (Coops et al., 1999). Earlier, in 1991, the cyanobacteria peak was registered in late summer-autumn in Erenciuc (LC4) (Stancu-Stoianovici, 1992). accounted for $30 \%$ of this variation. Based on these observations we can conclude that local environmental condition of each lake complex influence two times more the patterns of cyanobacteria biovolume comparing to season. Lower biovolume of cyanobacteria was 
recorded in spring for both years (Fig. 2 and Table S3) and was likely caused by the increased water level in this period, which predicted both genus richness and biovolume (Table 2).

Sometimes spring blooms can also occur, when sunlight intensity increases, but those blooms do not lead to cyanobacteria surface accumulation, known as scum (Török, 2005b).

Consistent with our results, the same tendency was also noticed during spring floods in 2013 (Florescu et al., 2015) in shallow lakes of a complex of wetland ecosystems, known as "inner Danube Delta”, located in Balta Mică a Brăilei Nature Park, upstream of the Danube Delta. In summer, densities of cyanobacteria increase because nutrients become more available (Török, 2005b). There are nonetheless situations in which the increase occurs in autumn, as it was the case of Microcystis blooms in the Isac (LC2) (Török, 2000-2001). Based on these assumptions, we presume that nutrients were released much later, since the cyanobacteria dominated alike in autumn, in at least Roșu-Puiu (Fig. 2, 4 and Table S3).

Environmental variables: Hypothesis 3

536 The Danube Delta is a mosaic of interconnected aquatic and terrestrial ecosystems with no

537 strict boundaries between them, and is strongly dependent on seasonal water inflow, especially on floods (Armaș \& Avram, 2009; Iordachi \& Van Assche, 2014). The significant differences between lakes situated North and South from the Sulina main branch have already been outlined (Nicolescu, 1992): lakes from the northern part form the fluvial delta, comprise

541 older lakes from the genesis point of view, and the sedimentation rate is higher here hence

542 explaining why lakes have a lower water level. Lakes situated in the southern part form the maritime delta and are lakes formed before the northern lakes, with a much lower sedimentation rate since they are not situated so close to the main braches. Moreover, their lakes bed are mostly mineral and are separated by the Caraorman sand beam. 
547 the shore length of the lakes, water level, coverage of the submerse macrophytes, water 548 transparency and velocity (Table 2, S5 and S6) are the most important predictors of LCs 549 differentiation. Cyanobacteria biovolume and genus richness are significantly and positively 550 correlated (Fig. S3), and we therefore expected to have similar predictors defining 551 cyanobacteria assemblages. The three LCs from the Danube Delta are significantly different 552 based on the biological and hydrogeomorphological characteristics of their lakes: LC2 553 comprises lakes with smallest shore length, medium water level and submerse macrophytes coverage, medium water retention time, higher transparency and low turbidity and water velocity. In contrast, LC4 includes lakes with the most meandering shorelines, highest water 556 level, velocity and turbidity, longest retention time, largest natural submerse macrophyte 557 coverage, and lowest water transparency. Lakes from LC3 are situated between the other two, with few exceptions already mentioned, that follow LC4 lakes tendency (Fig. S4). Surprisingly, only two of the tested from the best models tested on all significant hydrogeomorphological

560 predictors which differentiate between LCs were involved as well in genus richness 561 distribution: water level and velocity. More exactly, water level was involved in lake complex 562 differentiation, biovolume and richness distribution (Table 2), therefore, contradicting partially hypothesis $\mathrm{H}$ (3) in which we assumed that "hydrogeomorphological characteristics that differentiate the lake complexes influence also the cyanobacteria assemblages in terms of biovolume and genera richness". Connectivity and water residence time seems to play an important role in the

567 distribution of phytoplankton taxa in Danube Delta's shallow lakes (Guerold, 2000; Jamil et

568 al., 1999; Postolache, 2003, 2006). In addition, the development of cyanobacteria in relationship with the nutrient level and velocity of water circulation in the network of canals

570 has a large impact on lakes and lake complexes (Török, 2009a). Therefore, in lakes with low 571 residence time (Table S4), the cyanobacteria may be flushed away and have insufficient time 
to fully develop. As a result, the water transparency is higher, allowing more submerged

573

574

575

576

577

578

579

580

581

582

583

584

585

586

587

588

589

590

591

592

593

594

595

596 aquatic vegetation to grow (Oosterberg et al., 2000). During our study, some lakes of LC2 and LC3 experienced this situation.

Water level is the most important parameter that governs Danube Delta's shallow lakes, practically defining the ecosystems. Water level differs significantly among LCs and is a predictor in the best models of both cyanobacteria biovolume and genus richness (Table 2, S5 and S6). Elevation can also explain why we found the highest cyanobacteria diversity in LC4, as everything seems to be concentrated in the lower part of the Danube Delta, closer to the Back Sea. Beside these, other factors favor the highest cyanobacteria development in LC4 e.g. connectivity, distance from the main channel, water velocity and risk of flooding, all related to the water flowing direction to the sea after the flooding season (usually occurring in April-May).

The fact that flood risk was significant as predictor for cyanobacteria biovolume in our lake complexes is explained by the evidence that especially during flooding, there is a higher water input, and consequently of phytoplankton, from the main channel, (Güttler et al., 2013); this rises the diversity and biomass, in some cases. Flood risk was also negatively correlated with water level, implying that deep lakes had a lower flood risk and therefore a higher biomass. This was due to the low chance of washing, since the inflow and outflow of water is reduced. It is the case of most LC4 lakes and the biggest LC3 lakes (Fig. S4 and Table S4).

Beside the higher cyanobacteria biovolume registered in LC4 (Fig. S1), most of genera, both colonial and filamentous, were directly correlated with water level and flood risk (Fig. 6 and S5). Only three genera decreased in biovolume when the flood risk increased: Trichormus (former Anabaena), Jaaginema (former Oscillatoria) and Planktolyngbya (former Lyngbya), being flushed to LC4 (Table S2) which experienced the highest biovolume 
and genera richness of these cyanobacteria. Lakes from LC3 have the highest water input from the main channel (Table S4), which can explain why most lakes present different cyanobacteria assembly patterns. Only some of LC3 big lakes, far from the main channel,

600 namely Matița and Merhei behave similarly to those from LC4 with regards to cyanobacteria 601 biovolume and genus richness (Fig. S2).

602

\section{Conclusions}

604 In this study we compared cyanobacteria data from 19 Danube Delta lakes in which we identified 29 genera and found geographic and temporal patterns of cyanobacteria abundance (biovolume) and genus richness. We also found hydrogeomorphological characteristics that

607 define the lake complexes and that act as predictors for cyanobacteria occurrence and 608 distribution.

We found, in accordance with our expectation, higher values of cyanobacteria

610 biovolume and richness in spring and autumn, especially in lake complexes from the

611 southeastern part, revealing once again the heterogeneity of Danube Delta's shallow lakes.

612 Our findings strengthen the hypothesis that there is a significant difference among the LCs

613 and between the seasons regarding cyanobacteria assembly and supports earlier observations

614 about the uniqueness of lakes concerning their cyanobacterial assemblages. We also showed

615 that the PEG model can be applied to the Danube Delta. Furthermore, we showed that the

616 biovolume variation in our lakes could be better explained by lake complex than by season.

617 From the environmental variables water level, lakes connectivity and surface, channels

618 distance and flooding risk, explained the best cyanobacteria abundance and diversity.

619 Our study was performed during 2 years and 3 seasons. However, to accurately capture

620 the cyanobacteria dynamics in the Danube Delta Biosphere Reserve, studies that apply more

621 frequent samplings during the all seasons and throughout many years would be needed. 


\section{References}

Antilla, K., D. J. Barrington, H. Borges, L. X. Coggins, J. C. Comiso, D. R. Dietrich, B. Espina, J. Espinosa, H. Farrell \& M. Fraga, 2015. Climate Change and Marine and Freshwater Toxins. Walter de Gruyter GmbH \& Co KG.

Armaş, I. \& E. Avram, 2009. Perception of flood risk in Danube Delta, Romania. Natural Hazards 50:269-287.

Bellinger, E. G. \& D. C. Sigee, 2010. Introduction to freshwater algae. Freshwater Algae: Identification and Use as Bioindicators:1-40.

Bondar, C. \& N. Panin, 2001. The Danube Delta hydrologic database and modelling. GeoEcoMarina 5:5-52.

Botnariuc, N. \& A. Vădineanu, 1982. Ecologie. Editura Didactică şi Pedagogică.

Cărăuş, I. \& N. Nicolescu, 2006. Phytoplakton and its primary production in the Danube Delta In: Danube Delta. Genesis and Biodiversity. Backhuys Publishers, Leiden, The Netherlands.

Cardinale, B. J., J. E. Duffy, A. Gonzalez, D. U. Hooper, C. Perrings, P. Venail, A. Narwani, G. M. Mace, D. Tilman \& D. A. Wardle, 2012. Biodiversity loss and its impact on humanity. Nature 486:59.

Chaurasia, A., 2015. Cyanobacterial biodiversity and associated ecosystem services: introduction to the special issue. Springer.

Coops, H., L. L. Buijse, A. D. T. Buijse, A. Constantinescu, S. Covaliov, J. Hanganu, B. W. Ibelings, G. Menting, I. Navodaru \& W. Oosterberg, 2008. Trophic gradients in a large- river Delta: ecological structure determined by connectivity gradients in the Danube Delta (Romania). River Research and Applications 24:698-709.

Coops, H., J. Hanganu, M. Tudor \& W. Oosterberg, 1999. Classification of Danube Delta lakes based on aquatic vegetation and turbidity Biology, Ecology and Management of Aquatic Plants. Springer, 187-191.

De Senerpont Domis, L. N., J. J. Elser, A. S. Gsell, V. L. Huszar, B. W. Ibelings, E. Jeppesen, S. Kosten, W. M. Mooij, F. Roland \& U. Sommer, 2013. Plankton dynamics under different climatic conditions in space and time. Freshwater Biology 58:463-482.

Díez, B. \& K. Ininbergs, 2014. Ecological importance of cyanobacteria In: Sharma NK, Rai AK, Stal LJ., editors. Cyanobacteria. Vol. 106. Chichester (UK): John Wiley \& Sons, Ltd.

Dumitrache, A., M. Moldoveanu, L. Florescu, L. Parpală \& C. Sandu, 2014. A spatial approach of the environmental factors controlling plankton communities in the Danube Delta. Muzeul Olteniei Craiova Oltenia Studii şi comunicări Ştiinţele Naturii 30:197-204.

Enache, I., L. I. Florescu, M. Moldoveanu, M. I. Moza, L. Parpală, C. Sandu, P. Turko, G. Rîșnoveanu \& P. Spaak, 2019. Diversity and distribution of Daphnia across space and time in Danube Delta lakes explained by food quality and abundance. Hydrobiologia 842:39-54.

Erwin, K. L., 2009. Wetlands and global climate change: the role of wetland restoration in a changing world. Wetlands Ecology and management 17:71.

Florescu, M. H., M. M. Maxim, L. Momeu, M. Cîmpean \& K. P. Battes, 2015. Wetlands algal communities from Balta Mică a Brăilei Nature Park (Romania). Transylvanian Review of Systematical \& Ecological Research 17.

Fontana, S., M. K. Thomas, M. Moldoveanu, P. Spaak \& F. Pomati, 2018. Individual-level trait diversity predicts phytoplankton community properties better than species richness or evenness. The ISME journal 12:356366.

Friedrich, J., C. Dinkel, E. Grieder, S. Radan, D. Secrieru, S. Steingruber \& B. Wehrli, 2003. Nutrient uptake and benthic regeneration in Danube Delta Lakes. Biogeochemistry 64:373-398.

Găldean, N. \& D. M. Ruști, 2006. The Danube Delta ecosystems. In: Tudorancea C, Tudorancea MM, editors Danube Delta - Genesis and Biodiversity Leiden, The Netherlands: Blackhuys Publishers:95-104.

Gâstescu, P., M. Oltean, I. Nichersu \& A. Constantinescu, 1999. Ecosystems of the Romanian Danube Delta Biosphere Reserve. RIZA werkdocument 99:16-30.

Gâştescu, P. \& R. Știucă, 2008. Delta Dunarii Rezervatie a Biosferei. Editura CD-press, Bucuresti.

Giosan, L., 2014. Protect the world's deltas. Nature 516:31.

Guerold, F., 2000. Influence of taxonomic determination level on several community indices. Water Research 34:487-492.

Güttler, F. N., S. Niculescu \& F. Gohin, 2013. Turbidity retrieval and monitoring of Danube Delta waters using multi-sensor optical remote sensing data: An integrated view from the delta plain lakes to the westernnorthwestern Black Sea coastal zone. Remote Sensing of Environment 132:86-101.

Havens, K. E., 2008. Cyanobacteria blooms: effects on aquatic ecosystems Cyanobacterial harmful algal blooms: state of the science and research needs. Springer, 733-747. 
Hillebrand, H., C. D. Dürselen, D. Kirschtel, U. Pollingher \& T. Zohary, 1999. Biovolume calculation for pelagic and benthic microalgae. Journal of phycology 35:403-424.

Huber-Pestalozzi, G., 1938. Das Phytoplankton des Süßwassers. Systematik und Biologie. 1. Teil: Blaualgen, Bakterien, Pilze.-342 pp. E. Schweizerbart'sche Verlagsbuchhandlung, Stuttgart.

Ibellings, B., 1992. Cyanobacterial waterblooms: the role of buoyancy in water columns of varying stability. $\mathrm{Ph}$ D thesis Laboratory of Microbiology, University of Amsterdam:1-171.

Iordachi, C. \& K. Van Assche, 2014. The Bio-Politics of the Danube Delta: Nature, History, Policies. Lexington Books.

Irimuş, I. A., 2006. The hydrological regime of the Danube River in the deltaic sector. In: Tudorancea C, Tudorancea MM, editors Danube Delta - Genesis and Biodiversity Leiden, The Netherlands: Blackhuys Publishers:53-64.

Jamil, A., K. Lajtha, S. Radan, G. Ruzsa, S. Cristofor \& C. Postolache, 1999. Mussels as bioindicators of trace metal pollution in the Danube Delta of Romania. Hydrobiologia 392:143-158.

Kallis, G. \& D. Butler, 2001. The EU water framework directive: measures and implications. Water policy 3:125142.

Kauppila, P., G. Hällfors, P. Kangas, P. Kokkonen \& S. Basova, 1995. Late summer phytoplankton species composition and biomasses in the eastern Gulf of Finland. Ophelia 42:179-191.

Kleinteich, J., S. A. Wood, F. C. Küpper, A. Camacho, A. Quesada, T. Frickey \& D. R. Dietrich, 2012. Temperature-related changes in polar cyanobacterial mat diversity and toxin production. Nature Climate Change 2:356.

Komárek, J., 1998. Anagnostidis K. Cyanoprokaryota 1 Teil: Chroococcales Susswasserflora von Mitteleuropa Band 191.

Komárek, J., K. Anagnostidis \& I. Cyanoprokaryota, 1998. Teil Chroococcales. Band 19/1, Süßwasserflora von Mitteleuropa. Gaustav Fischer Verlag, Jena.

Komárek, J. \& K. C. Anagnostidis, 2005. Teil: Oscillatoriales. Subwasserflora von Mitteleuropa. Bridel B, Gaster G, Krienitz L, Schargerl M.(Hrs.)(19/2). Elsevier.

Komárek, J., J. Kaštovský, J. Mareš \& J. Johansen, 2014. Taxonomic classification of cyanoprokaryotes (cyanobacterial genera) Taxonomic classification of cyanoprokaryotes (cyanobacterial genera) 2014, using a polyphasic approach. Preslia 86:295-33.

Lauridsen, T. L., E. Jeppesen, S. A. Declerck, L. De Meester, J. M. Conde-Porcuna, W. Rommens \& S. Brucet, 2015. The importance of environmental variables for submerged macrophyte community assemblage and coverage in shallow lakes: differences between northern and southern Europe. Hydrobiologia 744:49-61.

Mateo, P., F. Leganés, E. Perona, V. Loza \& F. Fernández-Piñas, 2015. Cyanobacteria as bioindicators and bioreporters of environmental analysis in aquatic ecosystems. Biodiversity and Conservation 24:909948.

Moldoveanu, M. \& L. Florescu, 2013. Long - term analysis of cyanobacterial blooms in lake Roșu (Danube Delta). Muzeul Olteniei Craiova Oltenia Studii şi comunicări Ştiințele Naturii 29:244-251.

Moldoveanu, M., V. Zinevici, L. Parpală, D. Ionică, I. Păceșilă, A. Dumitrache, C. Sandu \& L. Florescu, 2015. The role of plankton communities in the functional capacity of the Danube Delta ecosystems - a long term study. Muzeul Olteniei Craiova Muzeul Olteniei Craiova Studii şi comunicări - Ştiinţele Naturii 31:183-188.

Năstase, A., 2009. Cercetări asupra biodiversităţii ihtiofaunei din Delta Dunării pentru exploatarea durabilă a resurselor piscicole. Universitatea "Dunărea de Jos" Galaţi.

Năstase, A. \& I. Năvodaru, 2008. Ichthyofauna of Danube delta lakes Sc Annals of DDI 14:37-46.

Nicolescu, N., 1992. The phytoplankton biodiversity in some lacustrian ecosystems from the Danube Delta in 1991. Analele Științifice ale Institutului Delta Dunării.

Oosterberg, W., M. Staras, L. Bogdan, A. Buijse, A. Constantinescu, H. Coops, J. Hanganu, B. W. Ibelings, G. Menting \& I. Navodaru, 2000. Ecological gradients in the Danube Delta lakes: present state and maninduced changes. Lelystad : Institute for Inland Water Management and Waste Water Treatment RIZA 170.

Paerl, H. W. \& J. Huisman, 2008. Climate - Blooms like it hot. Science 320:57-58.

Paerl, H. W. \& J. Huisman, 2009. Climate change: a catalyst for global expansion of harmful cyanobacterial blooms. Environmental Microbiology Reports 1:27-37.

Pantea, I., 1993. The study of optical phenomena records with different receivers in the aquatic ecosystems from Danube elta. Analele Științifice ale Institutului Delta Dunării:321.

Passy, S. I. \& P. Legendre, 2006. Are algal communities driven toward maximum biomass? Proceedings of the Royal Society B: Biological Sciences 273:2667-2674. 
Penning, W. E., B. Dudley, M. Mjelde, S. Hellsten, J. Hanganu, A. Kolada, M. van den Berg, S. Poikane, G. Phillips \& N. Willby, 2008. Using aquatic macrophyte community indices to define the ecological status of European lakes. Aquatic Ecology 42:253-264.

Pinheiro, J., D. Bates, S. DebRoy \& D. Sarkar, 2018. R Core Team (2018) nlme: linear and nonlinear mixed effects models. R package version 3.1-131.1. R software.

Postolache, C., 2003. Nutrient Management in the Danube Basin and its impact on the Black Sea. Scientific Report for the EVK1-2000-0603 Project

Postolache, C., 2006. The chemistry of the Danube Delta. In: Tudorancea C, Tudorancea MM, editors Danube Delta - Genesis and Biodiversity Leiden, The Netherlands: Blackhuys Publishers:65-95.

Postolache, C., G. Rîşnoveanu \& A. Vădineanu, 2006. Nitrogen and Phosphorous Excretion Rates by Tubificids from the Prahova River (Romania). Hydrobiologia 553:121-127.

Radu, E., M. D. Cirstea, C. CURUȚIU \& L. MĂRUȚESCU, 2017. Environmental parameters influencing the development of bacterioplankton communities from Danube Delta lakes. Romanian Biotechnological Letters 22:12661.

Reynolds, C. S., 1984. The ecology of freshwater phytoplankton. Cambridge University Press.

Romanescu, G., 1999. The Danube delta-some hydromorphodynamic aspects: deltaic changes during the modern and contemporary historical stages. Editura Universităţii din Suceava.

Romanescu, G., 2005. Morpho-hydrographical evolution of the Danube Delta. Editura Pim.

Russi, D., P. ten Brink, A. Farmer, T. Badura, D. Coates, J. Förster, R. Kumar \& N. Davidson, 2013. The economics of ecosystems and biodiversity for water and wetlands. IEEP, London and Brussels.

Sayer, C., N. Roberts, J. Sadler, C. David \& P. Wade, 1999. Biodiversity changes in a shallow lake ecosystem: a multi- proxy palaeolimnological analysis. Journal of Biogeography 26:97-114.

Schmitz, A. \& R. Nagel, 1995. Influence of 3, 4-dichloroaniline (3, 4-DCA) on benthic invertebrates in indoor experimental streams. Ecotoxicology and environmental safety 30:63-71.

Šmilauer, P. \& J. Lepš, 2014. Multivariate analysis of ecological data using CANOCO 5. Cambridge university press.

Sommer, U., Z. M. Gliwicz, W. Lampert \& A. Duncan, 1986. The PEG model of seasonal succession of planktonic events in fresh waters. Arch Hydrobiol 106:433-471.

Stancu-Stoianovici, E., 1992. Numeric and gravimetric aspects of phytoplankton communities in the areas of lenitic-terrestrial ecotone in the Danube Delta under the ecological conditions of the year 1991. Analele Știintififice ale Institutului Delta Dunării.

Stoch, F., M. Korn, S. Turki, L. Naselli-Flores \& F. Marrone, 2016. The role of spatial environmental factors as determinants of large branchiopod distribution in Tunisian temporary ponds. Hydrobiologia 782:37-51.

Sun, J. \& D. Liu, 2003. Geometric models for calculating cell biovolume and surface area for phytoplankton. Journal of plankton research 25:1331-1346.

Ter Braak, C. \& P. Šmilauer, 2012. Canoco reference manual and user's guide: software for ordination (version 50) microcomputer power. Ithaca, NY, USA:496.

Török, L., 2000-2001. Data on the influence of algae in submerged macrophytes. Scientific Annals of the Danube Delta Institute for Research and Development, Tulcea-Romania:165-170.

Török, L., 2005a. Ecological status of the Danube Delta Biosphere Reserve's Lakes. Scientific Annals of the Danube Delta Institute for Research and Development, Tulcea-Romania:112-115.

Török, L., 2005b. How the algal bloom is defined and quantified in Europe today? Scientific Annals of the Danube Delta Institute, Tulcea-Romania:4.

Török, L., 2005c. Seasonal succesion of phytoplankton from lakes of the Danube Delta. Acta Oecologica XII:1523.

Török, L., 2007. The dynamicsof the phytoplankton in some lakes of the Danube Delta Biosphere Reserve Brukenthal Acta Musei II:45-48.

Török, L., 2008a. Phytoplankton blooms of the Danube Delta Biosphere Reserve. Contributii Botanice 43.

Török, L., 2008b. Phytoplankton blooms of the Danube Delta Biosphere Reserve. Contribuţii Botanice, Grădina Botanică "Alexandru Borza", Cluj-Napoca XLIII:85-90.

Török, L., 2009a. A new approach to assess the phytoplankton biomass in Danube Delta Biosphere Reserve. Scientific Annals of the Danube Delta Institute, Tulcea-Romania 15:6.

Török, L., 2009b. Preliminary data on phytoplankton diurnal development in the Danube Delta. Scientific Annals of the Danube Delta Institute, Tulcea-Romania 15:6.

Török, L., 2011. The trend of phytoplankton development in Danube Delta's lakes. Scientific Annals of the Danube Delta Institute, Tulcea-Romania 17:89-98.

Török, L., L. Teodorof \& C. Năstase, 2008. The assessment of the nutrient pollution in Danube Delta Biosphere Reserve's surface water and proposal for risk evaluation of failing the environmental quality objective. Scientific Annals of the Danube Delta Institute, Tulcea-Romania 14:99-104. 
Utermöhl, H., 1958. Zur Vervollkommnung der quantitativen Phytoplankton-Methodik. Mitteilungen Internationale Vereinigung für theoretische und angewandte Limnologie 9:1-38.

Vădineanu, A., S. Cristofor \& G. Ignat, 1992. Phytoplankton and submerged macrophytes in the aquatic ecosystems of the Danube Delta during the last decade. Hydrobiologia 243/244:141-146.

Vădineanu, A., S. Cristofor, G. Ignat, C. Ciubuc, G. Rîșnoveanu, F. Bodescu \& N. Botnariuc, 2001. Structural and functional changes within the benthic communities of Danube Delta lakes. Internationale Vereinigung fur Theoretische und Angewandte Limnologie Verhandlungen 27:2571-2576.

Vespremeanu-Stroe, A., L. Preoteasa, F. Zăinescu \& F. Tătui, 2017. The evolution of Danube delta after Black Sea reconnection to World Ocean Landform Dynamics and Evolution in Romania. Springer, 521-549.

Xiao, L.-J., T. Wang, R. Hu, B.-P. Han, S. Wang, X. Qian \& J. Padisák, 2011. Succession of phytoplankton functional groups regulated by monsoonal hydrology in a large canyon-shaped reservoir. Water Research 45:5099-5109.

* R Core Development Team 2018. R: a language and environment for statistical computing. R Foundation for Statistical Computing, Vienna, Austria. Available at: http://www.rproject.org/.

\section{Tables list}

Table 1 Description of the lakes sampled from Danube Delta between 2013 and 2014, with their surfaces and GPS coordinates of the sampling points; lakes are listed from West to East. Lake complex Șontea-Furtuna (LC1), part of the fluvial delta, was not included in this study. Bolded variables were used for statistical analyses

Table 2 Significant variables of the best models used to differentiate lake complexes and to e xplain the dynamics of cyanobacteria biovolume and genus richness

\section{Figures list}

Fig. 1 Danube Delta map (created in Google maps, May 2017) with sampled lakes and lake complexes (LC) indicated in different colors. Șontea-Furtuna (LC1), Isac-Gorgova (LC2), Matița-Merhei (LC3) and Roșu-Puiu (LC4). Lakes from LC1 and Tătaru from LC4 were not included in this study

Fig. 2 Seasonal variation of biovolume (expressed in logarithmic scale) in the Danube Delta lake complexes: Gorgova - Uzlina (LC2), Matița-Merhei (LC3) and Roșu-Puiu (LC4) among three seasons: spring (S1), summer (S2) and autumn (S3)

Fig. 3 Genera biovolume - space-time biplot diagram from linear redundancy analysis (RDA) for the Danube Delta lake complexes: Gorgova - Uzlina (LC2), Matiţa-Merhei (LC3) 
and Roșu-Puiu (LC4) among three seasons: spring (SPR), summer (SUM) and autumn (AUT)

830 for cyanobacteria genera Anabaena (Anab), Anabaenopsis (Anas), Aphanizomenon (Apha), Aphanocapsa (Aphca), Coelosphaerium (Coel), Chroococcus (Chro), Jaaginemoa (Jaag), Johanseninema (Joha), Lyngbya (Lyng), Leptolyngbya (Lepto), Microcystis (Micr), Merismopedia (Meri), Oscillatoria (Osci), Planktolyngbya (Plan), Rhabdogloea (Rhab),

834 Snowella (Snow), Trichormus (Tric) and Wollea (Spha). Genera with less than four occurences were not included in the analysis

Fig. 4 Seasonal variation of cyanobacteria genus richness (expressed as number of genera) in the Danube Delta lake complexes: Gorgova - Uzlina (LC2), Matița-Merhei (LC3) and Roșu-

838 Puiu (LC4) among three seasons: spring (S1), summer (S2) and autumn (S3)

839 Fig. 5 Spatio-temporal pattern of cyanobacteria genus richness in the Danube Delta lake complexes displayed from West to East: Gorgova - Uzlina (LC2), Matița-Merhei (LC3) and

841 Roșu-Puiu (LC4). The overlaying discs represent the six samples taken from each lake during

842 the study period (the top disc is autumn 2014) and the disc color intensity represent the

843 cyanobacteria diversity (expressed as number of genera). Lake codes are given in Table 1

845 Fig. 6 Genera (in terms of biovolume) - lake characteristics biplot diagram from partial linear redundancy analysis (partial RDA) with lake complex as covariate. The codes for cyanobacteria genera are: Anabaena (Anab), Anabaenopsis (Anas), Aphanizomenon (Apha), Aphanocapsa (Aphca), Coelosphaerium (Coel), Chroococcus (Chro), Jaaginemoa (Jaag),

849 Johanseninema (Joha), Lyngbya (Lyng), Leptolyngbya (Lepto), Microcystis (Micr), Merismopedia (Meri), Oscillatoria (Osci), Planktolyngbya (Plan), Rhabdogloea (Rhab),

851 Snowella (Snow), Trichormus (Tric) and Wollea (Spha). Lake characteristics were: flooding 852 risk (floodris), water velocity (watervel) and peat deposits (peat). Genera with less than four 853 occurences were not included in the analysis 


\section{Supplementary tables list}

856 Table S1 Cyanobacteria genera and species identified in all 19 lakes from Danube Delta,

857 over the entire study period (2013-2014)

858 Table S2 Occurrence of cyanobacteria from Danube Delta lakes (expressed as genera

859 number) studied in 2013-2014 period; bolded genera represent those with less than four

860 occurrences and were not included in the analyses

861 Table S2 (continued) Occurrence of cyanobacteria genera from Danube Delta lakes

862 (expressed as genera number) studied in 2013-2014 period; bolded genera represent those

863 with less than four occurrences and were not included in the analyses

864 Table S3 Seasonal mean values (scientific number) of cyanobacteria biovolume and genus

865 richness recorded over two years and six in Danube Delta shallow lakes

866 Table S4 Characterization of the lake complexes from Danube Delta based on their

867 biological and hydrogeomorphological features

868 Table S4 (continued 1) Characterization of the lake complexes from Danube Delta based on

869 their biological and hydrogeomorphological features

870 Table S4 (continued 2) Characterization of the lake complexes from Danube Delta based on

871 their biological and hydrogeomorphological features

872 Table S5 Regression analysis using Spearman multiple correlation for the 19 lakes describing 873 variables (bolded and in orange color are variables strongly correlated)

874 Table S6 Regression analysis using Spearman multiple correlation for the 19 lakes describing 875 variables (bolded and in orange color are variables strong correlated) $-p$ values 876 
880 Fig. S1 Cyanobacteria: (a) biovolume and genus richness (b) for every lake complex, 881 displayed from West to East: Gorgova - Uzlina (LC2), Matiţa-Merhei (LC3) and Roșu-Puiu 882 (LC4)

883 Fig. S2 Cyanobacteria biovolume (a) and genus richness (b) for every studied lake (displayed 884 from West to East): Isac (IS), Uzlina (UZ), Cuibul cu Lebede (CL), Gorgostel (GR) part of 885 Gorgova- Uzlina (LC2, green), Trei Iezere (TI), La Amiază (LA), Bogdaproste (BG), Matița 886 (MA), Merhei (ME), Merhei Mic (MM), Lung (LU), Dracului (DR), Rădăcinoasele (RE), Babina (BA) part of Matița-Merhei (LC3, yellow) and Roșu (RO), Roșuleț (RT), Mândra (MD), Puiu (PU), Erenciuc (ER) part of Roșu-Puiu (LC4, purple)

889 Fig. S3 Scatterplot of cyanobacteria genus richness and biovolume (ln value) in the Danube 890 Delta lakes during the study period. The two parameters are significantly $(p<0.001)$ and 891 positively and strongly correlated according to Pearson correlation coefficient $(\rho=0.819)$

892 Fig. S4 Danube Delta lake parameters that significantly: (a) describe the lake complexes 893 (LC2 = Gorgova- Uzlina, LC3=Matița-Merhei and LC4=Roșu-Puiu), (b) predict 894 cyanobacteria biovolume and (c) cyanobacteria genus richness. The hydrogeomorphological 895 and biological features are described in Table S5 Fig. S5 Genera (in terms of biovolume) - lake characteristics biplot diagram from linear 897 redundancy analysis (RDA) with lake complex as covariate. The codes for cyanobacteria 898 genera are: Anabaena (Anab), Anabaenopsis (Anas), Aphanizomenon (Apha), Aphanocapsa 899 (Aphca), Coelosphaerium (Coel), Chroococcus (Chro), Jaaginemoa (Jaag), Johanseninema 900 (Joha), Lyngbya (Lyng), Leptolyngbya (Lepto), Microcystis (Micr), Merismopedia (Meri), 901 Oscillatoria (Osci), Planktolyngbya (Plan), Rhabdogloea (Rhab), Snowella (Snow),

902 Trichormus (Tric) and Wollea (Spha). Lake characteristics were: flooding risk (floodris), total 903 macrophyte coverage water velocity (macrotot), water level (depth) and phytoplankton 
904 diversity (phpdiv). Genera with less than four occurences were not included in the analysis.

905 


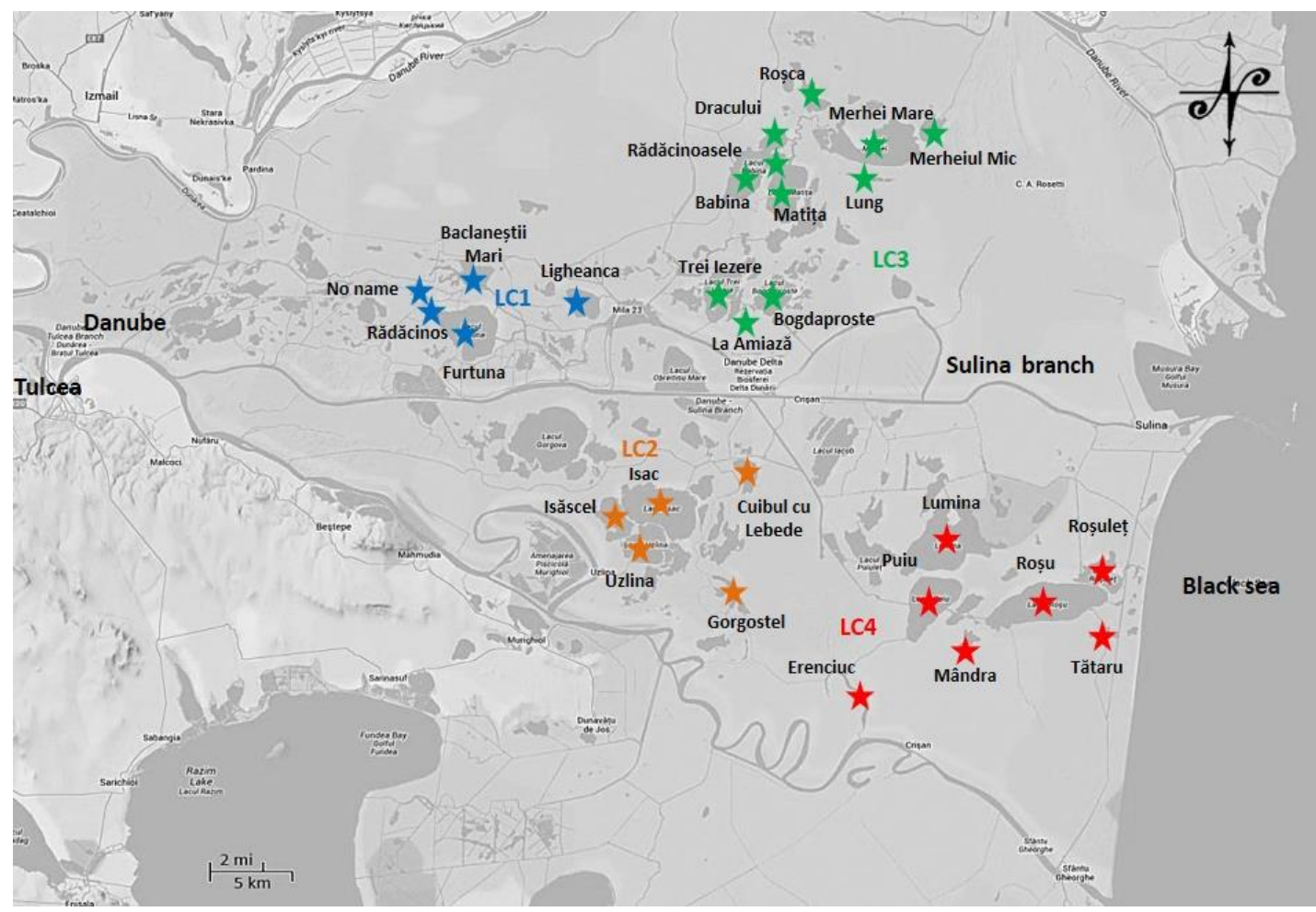

Fig. 1 Danube Delta map (created in Google maps, May 2017) with sampled lakes and lake complexes (LC) indicated in different colors. Șontea-Furtuna (LC1), Isac-Gorgova (LC2), Matița-Merhei (LC3) and Roșu-Puiu (LC4). Lakes from LC1, Isăscel from (LC2), Roșca from LC3 and Tătaru from LC4 were not included in this study

\section{Cyanobacteria biovolume}

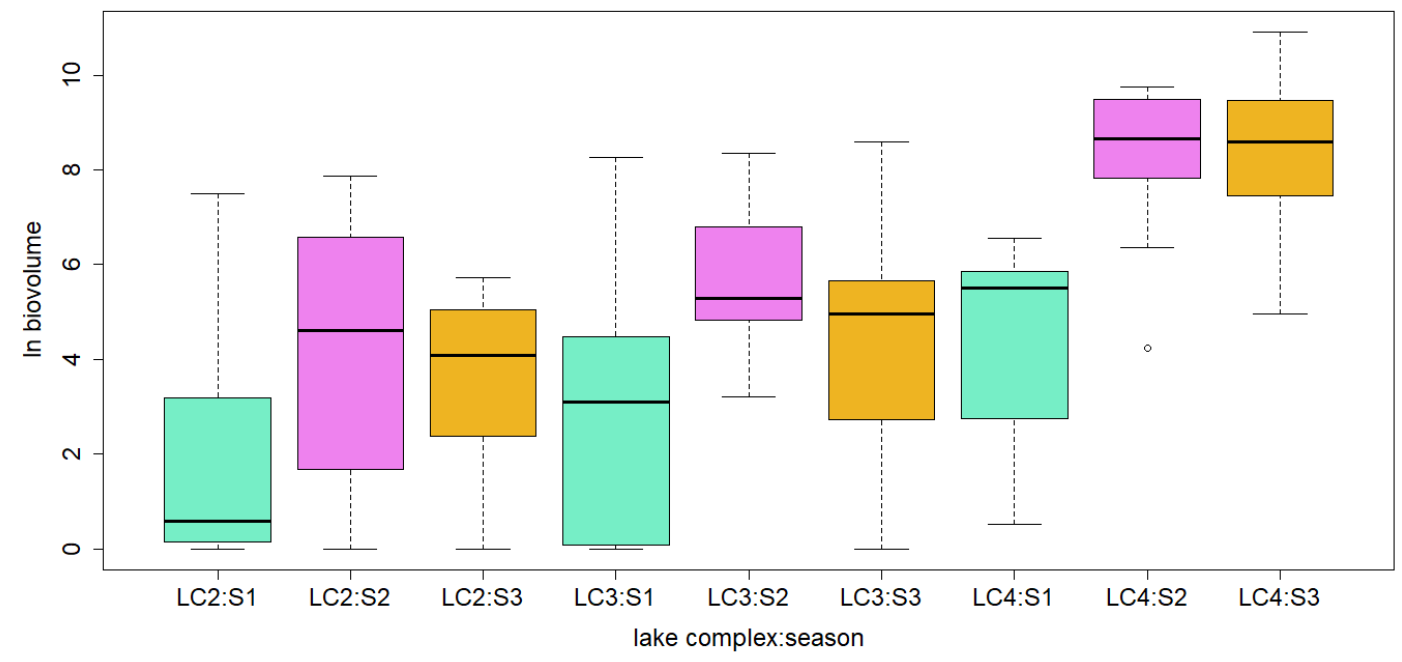

Fig. 2 Seasonal variation of biovolume (expressed in logarithmic scale) in the Danube Delta lake complexes:

Gorgova - Uzlina (LC2), Matița-Merhei (LC3) and Roșu-Puiu (LC4) among three seasons: spring (S1), summer (S2) and autumn (S3) 


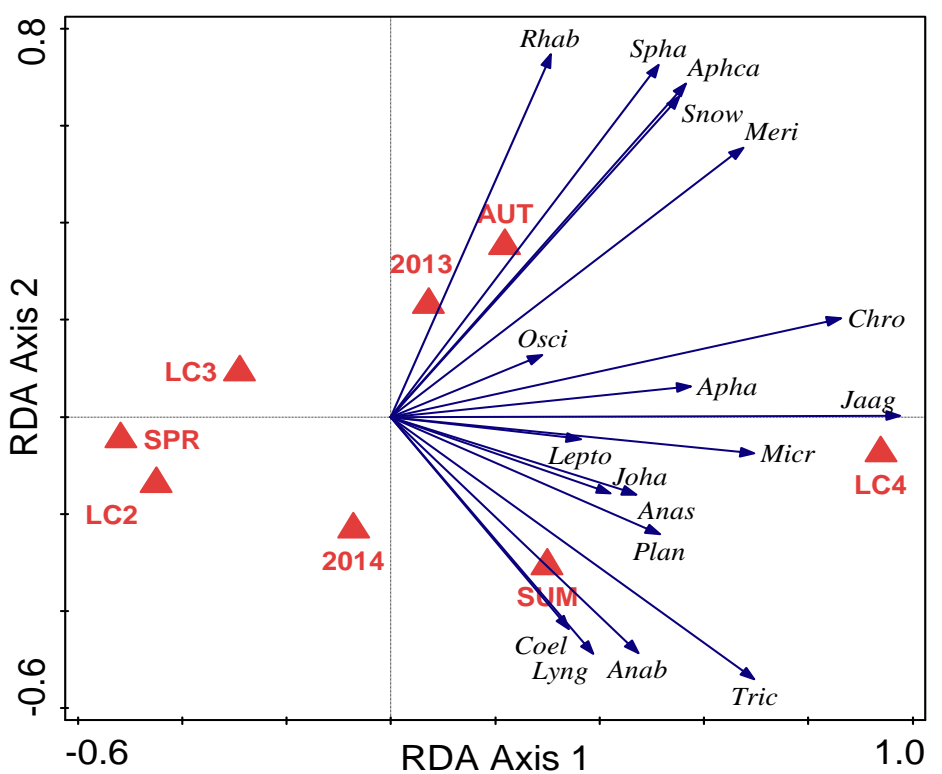

Fig. 3 Genera biovolume - space-time biplot diagram from linear redundancy analysis (RDA) for the Danube Delta lake complexes: Gorgova - Uzlina (LC2), Matița-Merhei (LC3) and Roșu-Puiu (LC4) among three seasons: spring (SPR), summer (SUM) and autumn (AUT) for cyanobacteria genera Anabaena (Anab), Anabaenopsis (Anas), Aphanizomenon (Apha), Aphanocapsa (Aphca), Coelosphaerium (Coel), Chroococcus (Chro), Jaaginemoa (Jaag), Johanseninema (Joha), Lyngbya (Lyng), Leptolyngbya (Lepto), Microcystis (Micr), Merismopedia (Meri), Oscillatoria (Osci), Planktolyngbya (Plan), Rhabdogloea (Rhab), Snowella (Snow), Trichormus (Tric) and Wollea (Spha). Genera with less than four occurences were not included in the analysis

\section{Cyanobacteria genus richness}

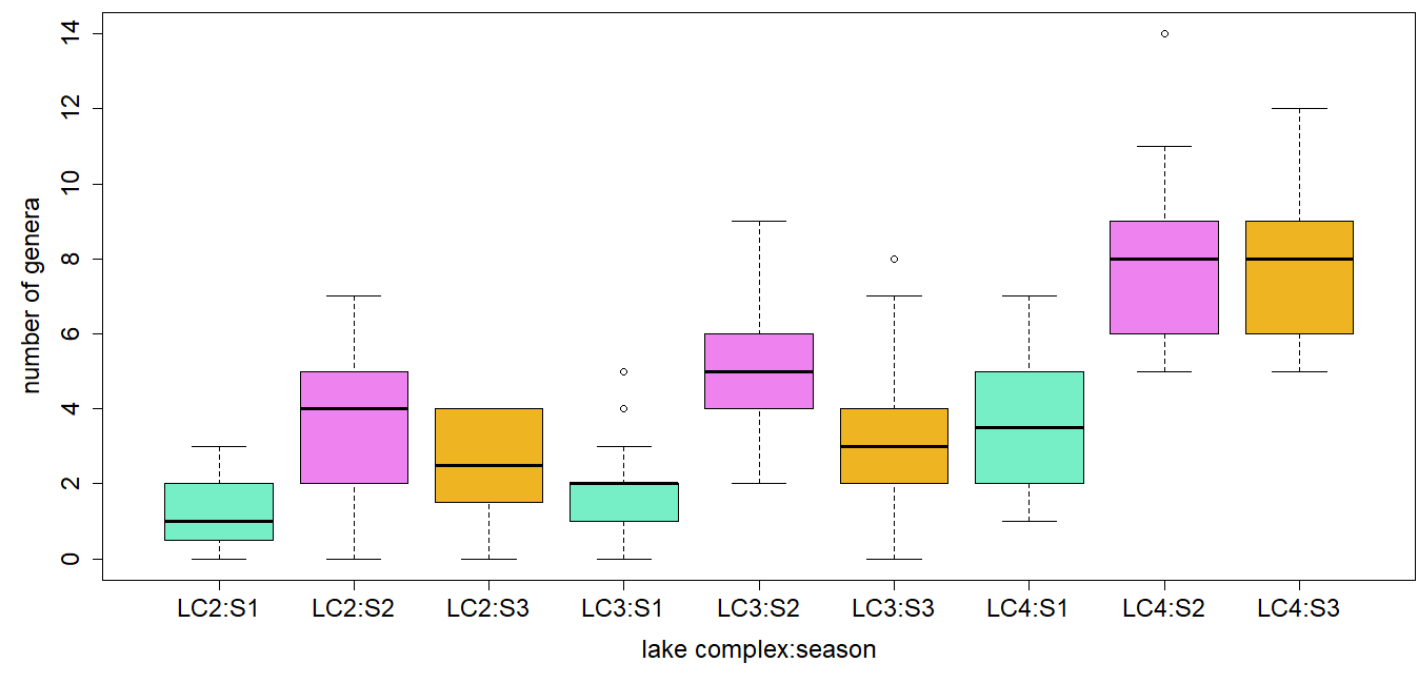

Fig. 4 Seasonal variation of cyanobacteria genus richness (expressed as number of genera) in the Danube Delta lake complexes: Gorgova - Uzlina (LC2), Matița-Merhei (LC3) and Roșu-Puiu (LC4) among three seasons: spring (S1), summer (S2) and autumn (S3) 


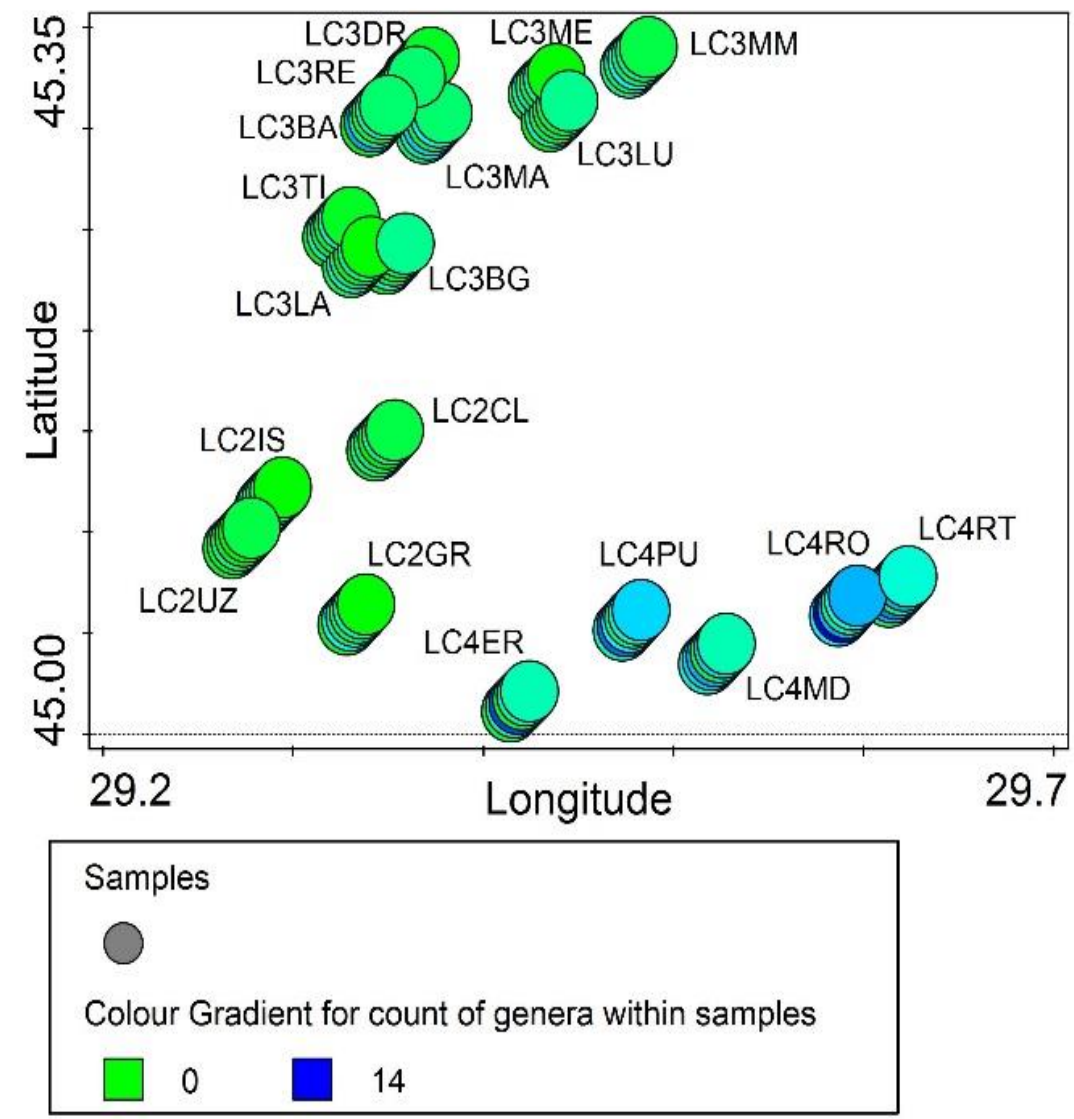

Fig. 5 Spatio-temporal pattern of cyanobacteria genus richness in the Danube Delta lake complexes displayed from West to East: Gorgova - Uzlina (LC2), Matița-Merhei (LC3) and Roșu-Puiu (LC4). The overlaying discs represent the six samples taken from each lake during the study period (the top disc is autumn 2014) and the disc color intensity represent the cyanobacteria diversity (expressed as number of genera). Lake codes are given in Table 1 


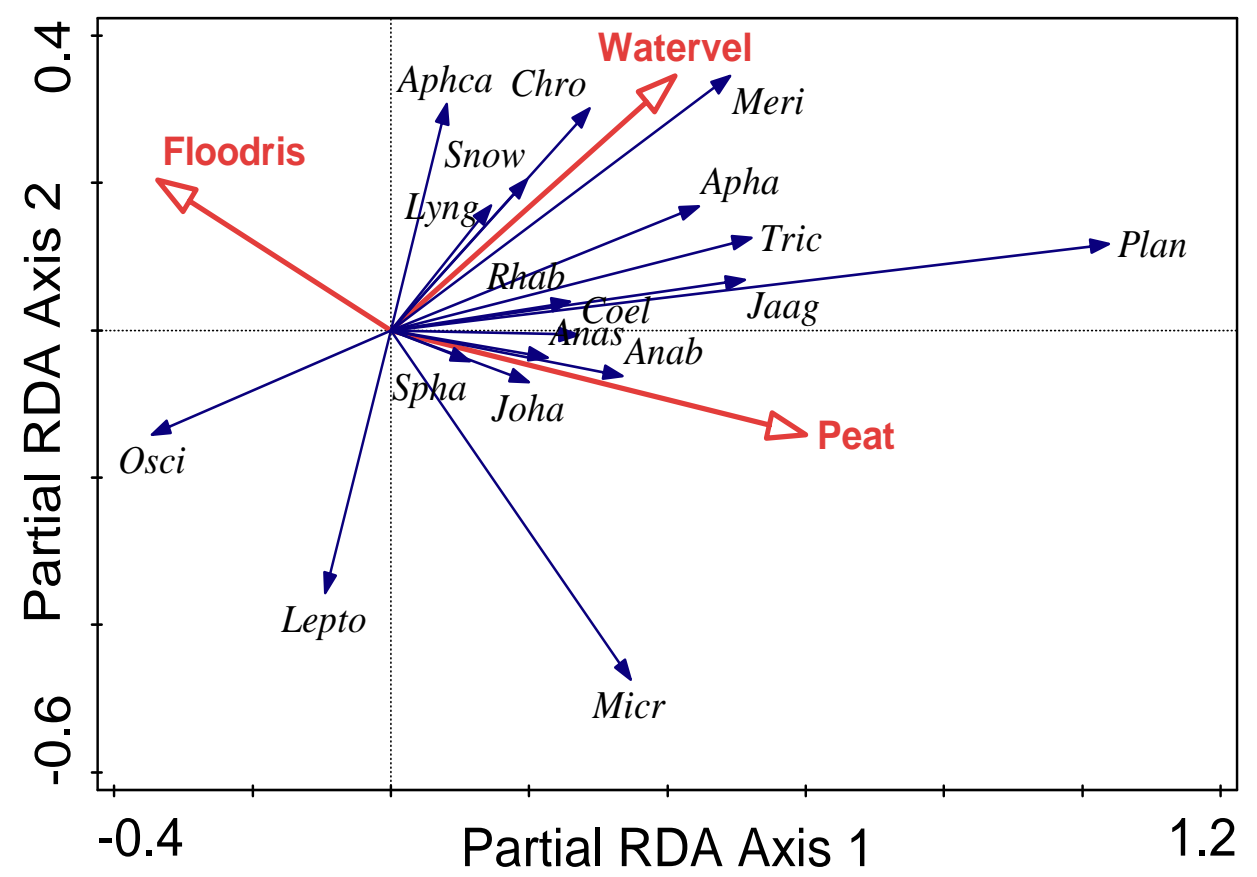

Fig. 6 Genera (in terms of biovolume) - lake characteristics biplot diagram from partial linear redundancy analysis (partial RDA) with lake complex as covariate. The codes for cyanobacteria genera are: Anabaena (Anab), Anabaenopsis (Anas), Aphanizomenon (Apha), Aphanocapsa (Aphca), Coelosphaerium (Coel), Chroococcus (Chro), Jaaginemoa (Jaag), Johanseninema (Joha), Lyngbya (Lyng), Leptolyngbya (Lepto), Microcystis (Micr), Merismopedia (Meri), Oscillatoria (Osci), Planktolyngbya (Plan), Rhabdogloea (Rhab), Snowella (Snow), Trichormus (Tric) and Wollea (Spha). Lake characteristics were: flooding risk (floodris), water velocity (watervel) and peat deposit (peat). Genera with less than four occurences were not included in the analysis 
Table 1 Description of the lakes sampled from Danube Delta between 2013 and 2014, with their surfaces and GPS coordinates of the sampling points; lakes are listed from West to East. Lake complex Şontea-Furtuna (LC1), part of the fluvial delta, was not included in this study. Bolded variables were used for statistical analyses

\begin{tabular}{|c|c|c|c|c|c|c|c|c|c|c|c|c|}
\hline $\begin{array}{c}\text { Lakes } \\
\text { complex } * * * \\
(\mathrm{~W} \rightarrow \mathrm{E})\end{array}$ & $\begin{array}{c}\text { Lakes } \\
\text { complex } \\
\text { code }\end{array}$ & $\begin{array}{l}\text { Lake } \\
\text { name }\end{array}$ & $\begin{array}{l}\text { Lake } \\
\text { code }\end{array}$ & $\begin{array}{l}\text { Latitude N } \\
\text { (DDM) }\end{array}$ & $\begin{array}{l}\text { Longitude E } \\
\text { (DDM) }\end{array}$ & $\begin{array}{l}\text { Delta } \\
\text { type }\end{array}$ & $\begin{array}{l}\text { Formation } \\
\text { age }\end{array}$ & $\begin{array}{c}\text { Surface } \\
\left(\mathbf{k m}^{2}\right)\end{array}$ & $\begin{array}{c}\text { Shore } \\
\text { length** } \\
(\mathrm{km})\end{array}$ & $\begin{array}{c}\text { Water } \\
\text { level** } \\
(\mathbf{m})\end{array}$ & $\begin{array}{c}\text { Transparency** } \\
\text { (m) }\end{array}$ & $\begin{array}{l}\text { Turbidity** } \\
\text { (NFU) }\end{array}$ \\
\hline \multirow{4}{*}{ Isac-Gorgova } & LC2 & Isac & IS & $45^{\circ} 06.728^{\prime}$ & $29^{\circ} 17.056^{\prime}$ & \multirow{4}{*}{ fluvial } & \multirow{4}{*}{ old } & $11.79 *$ & 10.2 & 2.1 & 1.8 & 4.6 \\
\hline & LC2 & Uzlina & $\mathrm{UZ}$ & $45^{\circ} 05.524^{\prime}$ & $29^{\circ} 16.070^{\prime}$ & & & $4.83^{*}$ & 6.93 & 1.5 & 1.3 & 6.1 \\
\hline & $\mathrm{LC} 2$ & Cuibul cu Lebede & CL & $45^{\circ} 08.426^{\prime}$ & $29^{\circ} 20.589^{\prime}$ & & & $2.02 * *$ & 5.16 & 1.5 & 1.5 & 6.7 \\
\hline & LC2 & Gorgostel & GR & $45^{\circ} 03.253^{\prime}$ & $29^{\circ} 19.692^{\prime}$ & & & $0.73^{*}$ & 5.73 & 2.0 & 1.4 & 7.4 \\
\hline \multirow{10}{*}{ Matița-Merhei } & LC3 & Trei Iezere & $\mathrm{TI}$ & $45^{\circ} 14.769^{\prime}$ & $29^{\circ} 19.212^{\prime}$ & \multirow{10}{*}{ fluvial } & \multirow{10}{*}{ old } & $5.74 *$ & 18.6 & 1.7 & 1.6 & 6.6 \\
\hline & LC3 & La Amiază & LA & $45^{\circ} 13.887^{\prime}$ & $29^{\circ} 19.826^{\prime}$ & & & $0.81 * *$ & 7.45 & 1.2 & 1.2 & 4.9 \\
\hline & LC3 & Bogdaproste & BG & $45^{\circ} 13.986^{\prime}$ & $29^{\circ} 20.935^{\prime}$ & & & $4.28 *$ & 11.9 & 1.5 & 1.5 & 3.2 \\
\hline & LC3 & Matița & MA & $45^{\circ} 17.862^{\prime}$ & $29^{\circ} 22.131^{\prime}$ & & & $6.87 *$ & 10.8 & 2.5 & 1.8 & 5.2 \\
\hline & LC3 & Merhei & ME & $45^{\circ} 19.020^{\prime}$ & $29^{\circ} 25.693^{\prime}$ & & & $12.27 *$ & 36.4 & 1.7 & 1.7 & 5.6 \\
\hline & LC3 & Merhei Mic & MM & $45^{\circ} 19.817^{\prime}$ & $29^{\circ} 28.596^{\prime}$ & & & $1.73^{*}$ & 8 & 1.3 & 1.3 & 4.1 \\
\hline & LC3 & Lung & LU & $45^{\circ} 18.220^{\prime}$ & $29^{\circ} 26.102^{\prime}$ & & & $0.74 *$ & 5.9 & 1.3 & 1.2 & 4.3 \\
\hline & LC3 & Dracului & DR & $45^{\circ} 19.508^{\prime}$ & $29^{\circ} 21.734^{\prime}$ & & & $1.83^{*}$ & 6.7 & 1.7 & 1.4 & 4.2 \\
\hline & LC3 & Rădăcinoasele & $\mathrm{RE}$ & $45^{\circ} 18.945^{\prime}$ & $29^{\circ} 21.287^{\prime}$ & & & $0.96 *$ & 10.9 & 1.6 & 1.2 & 5.8 \\
\hline & LC3 & Babina & BA & $45^{\circ} 18.090^{\prime}$ & $29^{\circ} 20.395^{\prime}$ & & & $4.99 *$ & 12.5 & 2.0 & 1.6 & 3.5 \\
\hline \multirow{5}{*}{ Roșu-Puiu } & LC4 & Roșu & $\mathrm{RO}$ & $45^{\circ} 03.507^{\prime}$ & $29^{\circ} 35.198^{\prime}$ & \multirow{5}{*}{ maritime } & \multirow{5}{*}{ new } & $14.31 *$ & 15.1 & 3.0 & 0.9 & 14.1 \\
\hline & LC4 & Roșuleț & RT & $45^{\circ} 04.080^{\prime}$ & $29^{\circ} 36.801^{\prime}$ & & & $4.35^{*}$ & 13.1 & 2.2 & 0.9 & 14.0 \\
\hline & LC4 & Mândra & MD & $45^{\circ} 02.082^{\prime}$ & $29^{\circ} 31.068^{\prime}$ & & & $1.47 * *$ & 7.57 & 1.9 & 1.0 & 9.9 \\
\hline & LC4 & Puiu & PU & $45^{\circ} 03.086^{\prime}$ & $29^{\circ} 28.372^{\prime}$ & & & $8.73 *$ & 13.3 & 3.1 & 0.9 & 8.2 \\
\hline & $\mathrm{LC} 4$ & Erenciuc & ER & $45^{\circ} 00.669^{\prime}$ & $29^{\circ} 24.850^{\prime}$ & & & $1.43^{*}$ & 14.3 & 2.6 & 1.6 & 20.9 \\
\hline
\end{tabular}

*DDNIRD = Danube Delta National Institute for Research and Development

**this study; surface and shore measurements were done using GoogleEarthPro software 
Table 2 Significant variables of the best models used to differentiate lake complexes and to explain the dynamics of cyanobacteria biovolume and genus richness

\begin{tabular}{|c|c|c|c|c|c|c|c|}
\hline \multirow[b]{2}{*}{ Variables that describe lakes* } & \multirow[b]{2}{*}{$\begin{array}{l}\text { Variable } \\
\text { code }\end{array}$} & \multicolumn{2}{|c|}{$\begin{array}{c}\text { characteristics that } \\
\text { differentiate lake complexes }\end{array}$} & \multicolumn{2}{|c|}{$\begin{array}{c}\text { predictors of } \\
\text { cyanobacteria biovolume }\end{array}$} & \multicolumn{2}{|c|}{$\begin{array}{l}\text { predictors of cyanobacteria } \\
\text { genus richness }\end{array}$} \\
\hline & & $\begin{array}{l}\text { Kruskal-Wallis } \\
\text { chi-squared }(H)\end{array}$ & $p$-value & $\begin{array}{l}\text { Likelihood Ratio } \\
\quad(L R)\end{array}$ & $p$-value & $\begin{array}{l}\text { Likelihood Ratio } \\
\qquad(L R)\end{array}$ & p-value \\
\hline Lake surfaces $\left(\mathrm{km}^{2}\right)$ & surface & & & & & 16.397 & $<0.001$ \\
\hline Lakes shore $(\mathrm{km})$ & shore & 6.5068 & 0.03864 & & & & \\
\hline Elevation (m) & elev & & & & & 7.904 & 0.004 \\
\hline Main channel distance (km) & mcdist & & & & & 12.529 & $<0.001$ \\
\hline Connectivity with main channel (categories) & connect & & & & & 6.072 & $<0.013$ \\
\hline Water level (m) & depth & 8.0693 & 0.01769 & 16.733 & $<0.001$ & 26.373 & $<0.001$ \\
\hline Submerse macrophyte (coverage units) & macrosub & 8.4187 & 0.01486 & & & & \\
\hline Total macrophyte (coverage units) & macrotot & & & 4.879 & 0.027 & & \\
\hline Water retention time (weeks) & retention & 8.2514 & 0.01615 & & & & \\
\hline Phytoplankton diversity (categories) & phpdiv & & & 10.554 & 0.001 & & \\
\hline Transparency (in $\%$ from the water level) ${ }^{* *}$ & trans_p & 10.898 & 0.004301 & & & & \\
\hline Flooding risk (categories) & floodris & & & 17.484 & $<0.011$ & & \\
\hline Water velocity $\left(\mathrm{m} \mathrm{s}^{-1}\right)$ & watervelo & 6.8217 & 0.03301 & & & 13.237 & $<0.001$ \\
\hline
\end{tabular}

*all the characteristics of lakes and lake complexes are detailed in Table 1 and Table S4

**transparency was considered both cause and effect of cyanobacteria biovolume and genus richness, therefore it was not included in the subsequent analyses

***water level was the only common predictor from all three sections 


\section{Electronic Supplementary Material}

for the article cited as Moza et al., 2020

\section{Geographical and temporal patterns of cyanobacteria assemblages in the Danube Delta lake complexes} in Hydrobiologia, $\mathrm{IF}=2.05, \mathrm{AI}=0.69$

Maria Iasmina Moza ${ }^{1, \$,}$, Carmen Postolache ${ }^{1,2, *}$, Ana Maria Benedek ${ }^{3}$, Mirela Moldoveanu ${ }^{4}$, Piet Spaak ${ }^{5}$

${ }^{1}$ Faculty of Biology, University of Bucharest, Department of Systems Ecology and Sustainable Development, Doctoral School in Ecology, Bucharest, Romania

${ }^{2}$ Research Institute of the University of Bucharest - ICUB, Bucharest, Romania

${ }^{3}$ Faculty of Science, "Lucian Blaga” University, Applied Ecology Research Centre, Sibiu, Romania

${ }^{4}$ Institute of Biology Bucharest, Department of Ecology, Taxonomy and Nature Conservation, Romanian Academy, Bucharest, Romania

${ }^{5}$ Swiss Institute for Environmental Science and Technology (Eawag), Dübendorf, Switzerland

\$Current working address: Foundation Conservation Carpathia, Wildlife Genetic Monitoring Laboratory, Brasov, Romania

Correspondence 1: Maria Iasmina Moza, Foundation Conservation Carpathia, Wildlife Genetic Monitoring Laboratory, Calea Feldioarei 18, 500450, Brasov, Romania

Tel.: +40743620132

E-mail: iasmina_moza@yahoo.com

Correspondence 2: Carmen Postolache, Faculty of Biology, University of Bucharest, Department of Systems Ecology and Sustainable Development, Doctoral School in Ecology, Splaiul Independenței no. 91-95, district 5, 050095, Bucharest, Romania

Tel.: +40 744495917

E-mail: carmen_postolache83@yahoo.com 
Table S1 Cyanobacteria genera and species identified in all 19 lakes from Danube Delta, over the entire study period (2013-2014)

\begin{tabular}{|c|c|c|}
\hline \multicolumn{3}{|c|}{ Cyanobacteria genera (code)/species } \\
\hline †Anabaena (Anab) & †Chroococcus (Chro) & †scillatoria (Osci) \\
\hline A. circinalis (Kütz.) Hansgirg 1886 & C. dispersus Lemmermann, E. 1904 & O. limosa C.Agardh ex Gomont 1892 \\
\hline A. spiroides Klebahn 1895 & C. limneticus Lemmermann, E. 1898 & O. tenuis C.Agardh ex Gomont 1892 \\
\hline A. $s p$ & C. minutus Nägeli, C. 1849 & O. sp. \\
\hline †Johanseninema (Joha) & C. dimidiatus & $\dagger$ Jaaginema (Jaag) \\
\hline J.constrictum (Szafer) Hasler, Dvorák \& Poulícková 2014 & C. sp. & J. minimum Anagnostidis \& Komárek 1988 \\
\hline †Dolichospermum (Doli) & Rhabdogloea (Rhab) & †icrocystis (Micr) \\
\hline $\begin{array}{l}\text { D. flosaquae (Brébisson ex Bornet \& Flahault) P.Wacklin, L.Hoffmann } \\
\text { \& J.Komárek } 2009\end{array}$ & R. smithii (Chodat \& F.Chodat) Komárek 1983 & M. aeruginosa Kützing 1846 \\
\hline D. scheremetie (Elenkin) Wacklin, L.Hoffmann \& Komárek 2009 & Gloeocapsa (Glsa) & M. flos-aquae Kirchner, O. 1898 \\
\hline$\dagger$ Trichormus (Tric) & G. $s p$. & M. pulverea Forti, A. 1907 \\
\hline $\begin{array}{l}\text { T. variabilis (Kützing ex Bornet \& Flahault) Komárek \& Anagnostidis } \\
1989\end{array}$ & Gloeotece (Glce) & M. smithii Komárek \& Anagnostidis 1995 \\
\hline †Aphanizomenon (Apha) & G. $s p$ & M. wessenbergii Teiling 1941 \\
\hline A. flos-aquae Ralfs ex Bornet \& Flahault 1886 & †Snowella $($ Snow) & M. sp. \\
\hline †Aphanocapsa (Aphca) & S. lacustris Komárek, J. \& Hindák, F. 1988 & †Leptolyngbya (Lepto) \\
\hline A.sp. & Loriella (Lori) & L. tenuis Anagnostidis \& Komárek 1988 \\
\hline Aphanothece (Aphce) & L. $s p$. & †Phormidium (Phor) \\
\hline A. $s p$. & †Planktolyngbya (Plan) & P. sp. \\
\hline Coelosphaerium (Coel) & P. contorta Anagnostidis \& Komárek 1988 & Rivularia (Rivu) \\
\hline C. kuetzingianum Nägeli 1849 & P. limnetica Komárková-Legnerová \& Cronberg 1992 & R. sp. \\
\hline C. $s p$. & †Lyngbya (Lyng) & Spirulina (Spir) \\
\hline Woronichinia (Woro) & L. $s p$. & S. sp. \\
\hline W. naegeliana (Unger) Elenkin 1933 & Wollea (Woll)/Sphaerozyga (Spha) & †Merismopedia (Meri) \\
\hline Cylindrospermum (Cylum) & W. saccata Bornet \& Flahault 1886 & M. glauca Kützing 1845 \\
\hline C. maius Kützing ex Bornet \& Flahault 1888 & †Anabaenopsis (Anas) & M. punctata Meyen 1839 \\
\hline †Cylindrospermopsis (Cylis) & A. elenkinii V.V.Miller 1923 & M. tenuissima Lemmermann 1898 \\
\hline C. $s p$. & & M. $s p$. \\
\hline
\end{tabular}

$\dot{\dagger}=$ genera of cyanobacteria with toxic potential; any genera that had at least one species mentioned in literature as toxic was classified as being with toxic potential 
Table S2 Occurrence of cyanobacteria from Danube Delta lakes (expressed as genera number) studied in 2013-2014 period; bolded genera represent those with less than 4 occurrences and were not included in the analyses

\begin{tabular}{|c|c|c|c|c|c|c|c|c|c|c|c|c|c|c|c|c|c|c|c|c|c|}
\hline \multirow{2}{*}{\multicolumn{2}{|c|}{$\begin{array}{l}\text { Complex/ } \\
\text { lake code }\end{array}$}} & \multicolumn{20}{|c|}{ Cyanobacteria genera/species number } \\
\hline & & $\begin{array}{c}\text { Anab } \\
(5)\end{array}$ & $\begin{array}{c}\text { Anas } \\
\text { (1) }\end{array}$ & $\begin{array}{l}\text { Apha } \\
\text { (1) }\end{array}$ & $\begin{array}{c}\text { Aphca } \\
\text { (1) }\end{array}$ & $\begin{array}{c}\text { Chro } \\
(5)\end{array}$ & $\begin{array}{c}\text { Cylis } \\
\text { (1) }\end{array}$ & $\begin{array}{c}\text { Cylum } \\
\text { (1) }\end{array}$ & $\begin{array}{c}\text { Doli } \\
\text { (2) }\end{array}$ & $\begin{array}{c}\text { Jaag } \\
\text { (1) }\end{array}$ & $\begin{array}{c}\text { Joha } \\
\text { (1) }\end{array}$ & $\begin{array}{c}\text { Lepto } \\
\text { (1) }\end{array}$ & $\begin{array}{c}\text { Lyng } \\
\text { (1) }\end{array}$ & $\begin{array}{c}\text { Meri } \\
(4)\end{array}$ & $\begin{array}{l}\text { Micr } \\
(6)\end{array}$ & $\begin{array}{l}\text { Osci } \\
\text { (3) }\end{array}$ & $\begin{array}{l}\text { Phor } \\
\text { (1) }\end{array}$ & $\begin{array}{c}\text { Plan } \\
(2)\end{array}$ & $\begin{array}{c}\text { Snow } \\
\text { (1) }\end{array}$ & $\begin{array}{l}\text { Tric } \\
\text { (1) }\end{array}$ & Total \\
\hline & IS & 1 & & & & 1 & & & & 1 & & & & 1 & 1 & & & & & & 5 \\
\hline \multirow{3}{*}{$\mathrm{LC} 2$} & UZ & & & & & 1 & & & & 1 & & & & 1 & 1 & & & & & & 4 \\
\hline & CL & 1 & & & & 1 & & & & 1 & & & 1 & 1 & 1 & & & & & & 6 \\
\hline & GR & 1 & & & & 1 & & & & 1 & 1 & & 1 & 1 & 1 & & 1 & 1 & & 1 & 10 \\
\hline \multirow{9}{*}{ LC3 } & TI & & & & & 1 & & & & 1 & & 1 & & 1 & 1 & 1 & & & 1 & & 7 \\
\hline & LA & & & & & 1 & & & & 1 & & & & 1 & 1 & 1 & 1 & 1 & & & 7 \\
\hline & BG & 1 & & & & 1 & & & & 1 & & & & 1 & 1 & 1 & & 1 & 1 & & 8 \\
\hline & MA & 1 & & 1 & & 1 & & & & 1 & & & 1 & 1 & 1 & & & 1 & 1 & 1 & 10 \\
\hline & $\mathrm{ME}$ & 1 & & & & 1 & & & & 1 & & & 1 & 1 & 1 & & & 1 & 1 & & 8 \\
\hline & $\mathrm{MM}$ & & & & & 1 & & & & 1 & 1 & & & 1 & 1 & & & 1 & 1 & & 7 \\
\hline & DR & 1 & & 1 & & 1 & & & & 1 & & & 1 & 1 & 1 & & & & & 1 & 8 \\
\hline & $\mathrm{RE}$ & 1 & & & & 1 & & & & 1 & & & & 1 & 1 & & & & 1 & & 6 \\
\hline & BA & 1 & & & 1 & 1 & & & & 1 & 1 & & & 1 & 1 & & & & 1 & 1 & 9 \\
\hline \multirow{5}{*}{ LC4 } & RO & 1 & & 1 & 1 & 1 & & 1 & & 1 & 1 & & & 1 & 1 & 1 & & 1 & 1 & 1 & 13 \\
\hline & RT & 1 & & 1 & 1 & 1 & & & & 1 & 1 & 1 & 1 & 1 & 1 & & & 1 & 1 & 1 & 13 \\
\hline & MD & 1 & 1 & 1 & 1 & 1 & 1 & & & 1 & & & 1 & 1 & 1 & 1 & 1 & 1 & 1 & 1 & 15 \\
\hline & $\mathrm{PU}$ & 1 & 1 & & & 1 & 1 & & 1 & 1 & 1 & 1 & 1 & 1 & 1 & & 1 & 1 & & 1 & 14 \\
\hline & ER & 1 & & 1 & 1 & 1 & 1 & & & 1 & 1 & 1 & 1 & 1 & 1 & 1 & & & 1 & 1 & 14 \\
\hline Total & & 15 & 2 & 6 & 5 & 19 & 3 & 1 & 1 & 19 & 7 & 4 & 9 & 19 & 19 & 6 & 4 & 10 & 12 & 9 & \\
\hline
\end{tabular}

*legend: Anab=Anabaena, Anas=Anabaenopsis, Apha=Aphanizomenon, Aphca=Aphanocapsa, Chro=Chroococcus, Cylis=Cylindrospermopsis, Cylum=Cylindrospermum, Doli=Dolichospermum, Jaag=Jaaginema, Joha=Johanseninema, Lepto=Leptolyngbya, Lyng=Lyngbya, Meri=Merismopedia, Micr=Microcystis, Osci=Oscillatoria, Phor=Phormidium, Plan=Planktolyngbya, Snow=Snowella and Tric=Trichormus; $(1-6)=$ species number for each genera signaled over the study period 
Table S2 (continued) Occurrence of cyanobacteria genera from Danube Delta lakes (expressed as genera number) studied in 2013-2014 period; bolded genera represent those with less than 4 occurrences and were not included in the analyses

\begin{tabular}{|c|c|c|c|c|c|c|c|c|c|c|c|c|}
\hline \multicolumn{2}{|c|}{$\begin{array}{l}\text { Lake complex/ } \\
\text { Lake code }\end{array}$} & $\begin{array}{c}\text { Aphce } \\
\text { (1) }\end{array}$ & $\begin{array}{l}\text { Coel } \\
\text { (2) }\end{array}$ & $\begin{array}{c}\text { Rhab } \\
\text { (1) }\end{array}$ & \multicolumn{5}{|c|}{ Cyanobacteria genera/species number } & Woro & Woll & Total \\
\hline & IS & & 1 & 1 & & & . & & & & 1 & 4 \\
\hline \multirow[t]{7}{*}{ LC2 } & UZ & & & 1 & & & & & & & & 1 \\
\hline & CL & & & 1 & & & & & & & & 1 \\
\hline & GR & & & 1 & & & & & 1 & & & 2 \\
\hline & TI & & 1 & 1 & & & & & 1 & & & 3 \\
\hline & LA & & & 1 & & & & & & 1 & 1 & 3 \\
\hline & BG & & 1 & 1 & & & & & & & & 2 \\
\hline & MA & & & 1 & 1 & & & & & & & 2 \\
\hline \multirow[t]{8}{*}{ LC3 } & ME & & 1 & 1 & & 1 & & & & & & 3 \\
\hline & MM & & & 1 & & & & & & & 1 & 2 \\
\hline & LU & & 1 & 1 & & & & & & & & 2 \\
\hline & DR & & & 1 & & 1 & & 1 & 1 & & & 4 \\
\hline & $\mathrm{RE}$ & & 1 & 1 & & & & & & 1 & & 3 \\
\hline & $\mathrm{BA}$ & & & 1 & & & & & & & & 1 \\
\hline & RO & 1 & 1 & 1 & & & & & & & 1 & 4 \\
\hline & RT & & & 1 & & & & & & & 1 & 2 \\
\hline \multirow[t]{4}{*}{ LC4 } & MD & & & 1 & & & & & & & 1 & 2 \\
\hline & PU & & 1 & 1 & & & & & & & 1 & 3 \\
\hline & ER & & 1 & 1 & & & & & & & 1 & 3 \\
\hline & Total & 1 & 9 & 19 & 1 & 2 & 1 & 1 & 3 & 2 & 8 & \\
\hline
\end{tabular}

*legend: Aphce=Aphanothece, Coel=Coelosphaerium, Rhab=Rhabdogloea, Glsa=Gloeocapsa,

Glce $=$ Gloeotece, Lori $=$ Loriella, Rivu $=$ Rivularia, Spir $=$ Spirulina, Woro $=$ Woronichinia,

Woll $($ Spha $)=$ Wollea $($ Sphaerozyga $) ;(1-2)=$ species number for each genera signaled over the study period 
Table S3 Seasonal mean values (scientific number) of cyanobacteria biovolume and genus richness recorded over two years in Danube Delta shallow lakes

\begin{tabular}{|c|c|c|c|c|c|c|c|c|}
\hline \multicolumn{5}{|c|}{ Cyanobacteria biovolume } & \multicolumn{4}{|c|}{ Cyanobacteria genus richness } \\
\hline Lake & $\begin{array}{l}\text { Spring } \\
\left(\mu m^{3} L^{-1}\right)\end{array}$ & $\begin{array}{l}\text { Summer } \\
\left(\mu m^{3} L^{-1}\right)\end{array}$ & $\begin{array}{l}\text { Autumn } \\
\left(\mu m^{3} L^{-1}\right)\end{array}$ & $\begin{array}{c}\text { Mean per } \\
\text { lake complex }\end{array}$ & Spring & Summer & Autumn & $\begin{array}{c}\text { Total per } \\
\text { lake complex }\end{array}$ \\
\hline Isac (IS) & $9 . \mathrm{E}+08$ & $2 . \mathrm{E}+07$ & 2.E+07 & & 2 & 4 & 2 & \\
\hline Uzlina (UZ) & $6 . \mathrm{E}+05$ & 8.E+05 & 3.E+08 & 4.E+09 & 1 & 1 & 3 & 14 \\
\hline Cuibul cu Lebede (CL) & 2.E+05 & 8.E+08 & 4.E+07 & & 1 & 4 & 2 & \\
\hline Gorgostel (GR) & 3.E+07 & 2.E+09 & $6 . E+07$ & & 2 & 6 & 3 & \\
\hline Trei Iezere (TI) & $5 . \mathrm{E}+07$ & 1.E+09 & 7.E+07 & & 2 & 6 & 2 & \\
\hline La Amiază (LA) & 2.E+06 & 1.E+09 & 1.E+08 & & 2 & 5 & 2 & \\
\hline Bogdaproste (BG) & 2.E+09 & 9.E+08 & 3.E+07 & & 1 & 5 & 3 & \\
\hline Matița (MA) & $5 . \mathrm{E}+07$ & $5 . \mathrm{E}+08$ & 3.E+09 & & 3 & 6 & 6 & \\
\hline Merhei (ME) & $9 . E+07$ & 2.E+08 & 8.E+07 & $2 . E+10$ & 2 & 5 & 2 & 14 \\
\hline Merhei Mic (MM) & 2.E+08 & 8.E+07 & 3.E+08 & & 4 & 4 & 5 & \\
\hline Lung (LU) & 4.E+08 & 1.E+08 & 1.E+08 & & 1 & 4 & 3 & \\
\hline Dracului (DR) & $3 . E+07$ & 2.E+08 & 2.E+08 & & 4 & 5 & 3 & \\
\hline Rădăcinoasele (RE) & $5 . E+04$ & 2.E+09 & 2.E+09 & & 1 & 6 & 4 & \\
\hline Babina (BA) & 4.E+07 & 4.E+08 & 2.E+08 & & 1 & 7 & 4 & \\
\hline Roșu (RO) & 3.E+08 & 8.E+09 & 3. $E+10$ & & 6 & 11 & 9 & \\
\hline Roșuleț (RT) & 5.E+08 & 1.E+10 & 7.E+09 & & 3 & 9 & 8 & \\
\hline Mândra (MD) & 2.E+08 & 7.E+09 & 9.E+09 & 1.E+11 & 4 & 8 & 7 & 19 \\
\hline Puiu (PU) & 2.E+08 & 9.E+09 & 7.E+09 & & 5 & 9 & 7 & \\
\hline Erenciuc (ER) & 4.E+06 & 1.E+09 & 4.E+09 & & 2 & 5 & 9 & \\
\hline
\end{tabular}


Table S4 Characterization of the lake complexes from Danube Delta based on their biological and hydro-geomorphological features

\begin{tabular}{|c|c|c|c|c|c|c|c|c|c|}
\hline $\begin{array}{c}\text { Lakes } \\
\text { complex * } \\
(\mathrm{W} \rightarrow \mathrm{E})\end{array}$ & $\begin{array}{c}\text { Lake } \\
\text { name and code }\end{array}$ & $\begin{array}{c}\text { Main } \\
\text { channel } \\
\text { distance** } \\
(\mathbf{k m}) \\
\end{array}$ & $\begin{array}{l}\text { Connectivity } \\
\text { with the main } \\
\text { river branch } \\
\text { Sulina }^{\#, 1}\end{array}$ & $\begin{array}{l}\text { Water input } \\
\text { from the main } \\
\text { channel*** } \\
\left(\mathrm{m}^{2} / \mathrm{s}\right)\end{array}$ & $\begin{array}{l}\text { Lake complex } \\
\text { mean altitude } \\
\text { (m) }\end{array}$ & $\begin{array}{l}\text { Lakes complex } \\
\text { surface }^{1} \\
\text { (thousands ha) }\end{array}$ & $\begin{array}{l}\text { Elevation** } \\
\text { (m) }\end{array}$ & $\begin{array}{l}\text { Flooding } \\
\text { risk }^{\#, 2,3,4,5}\end{array}$ & $\begin{array}{c}\text { Transparency** } \\
(\%)\end{array}$ \\
\hline \multirow{4}{*}{$\begin{array}{l}\text { Isac-Gorgova } \\
\text { (LC2) }\end{array}$} & Isac (IS) & 10.4 & good & \multirow{4}{*}{8} & \multirow{4}{*}{0.16} & \multirow{4}{*}{23.2} & -1 & very high & 85.7 \\
\hline & Uzlina (UZ) & 13.8 & good & & & & -1 & very high & 89.9 \\
\hline & Cuibul cu Lebede (CL) & 7.24 & good & & & & -2 & high & 93.3 \\
\hline & Gorgostel (GR) & 21.75 & poor & & & & -2 & low & 66.3 \\
\hline \multirow{10}{*}{$\begin{array}{l}\text { Matița-Merhei } \\
\text { (LC3) }\end{array}$} & Trei Iezere (TI) & 11.5 & good & \multirow{10}{*}{27.6} & \multirow{10}{*}{0.7} & \multirow{10}{*}{20.5} & -1 & medium & 97.3 \\
\hline & La Amiază (LA) & 13.24 & medium & & & & -2 & low & 95.7 \\
\hline & Bogdaproste (BG) & 4.95 & good & & & & -2 & low & 95.4 \\
\hline & Matița (MA) & 25.3 & good & & & & -1 & low & 70.9 \\
\hline & Merhei (ME) & 19.5 & poor & & & & -1 & high & 98.5 \\
\hline & Merhei Mic (MM) & 22.68 & poor & & & & -1 & high & 97.0 \\
\hline & Lung (LU) & 17.7 & poor & & & & -2 & low & 88.4 \\
\hline & Dracului (DR) & 30.21 & poor & & & & -1 & low & 83.3 \\
\hline & Rădăcinoasele (RE) & 31.79 & poor & & & & 0 & low & 74.7 \\
\hline & Babina (BA) & 28.1 & medium & & & & -1 & medium & 78.6 \\
\hline \multirow{5}{*}{$\begin{array}{l}\text { Roșu-Puiu } \\
\text { (LC4) }\end{array}$} & Roșu (RO) & 13.48 & medium & \multirow{4}{*}{9.4} & \multirow{5}{*}{0.22} & \multirow{5}{*}{33.1} & -1 & low & 26.3 \\
\hline & Roșuleț (RT) & 11.15 & medium & & & & -1 & low & 37.0 \\
\hline & Mândra (MD) & 18.26 & medium & & & & 0 & low & 50.9 \\
\hline & Puiu (PU) & 20.95 & medium & & & & -1 & medium & 25.9 \\
\hline & Erenciuc (ER) & 29.55 & good & 1.2 & & & -2 & high & 62.8 \\
\hline
\end{tabular}

*lakes complex Şontea-Furtuna (LC1), part of the fluvial delta, was not included in this study

**this study; measurements were done using GoogleEarthPro software

***DDNIRD = Danube Delta National Institute for Research and Development

****bolded characteristics were included in hydro-geomorphologycal analyses as well

\#for each category a number from 1 to 6 was atributed for statistical analyses 
Table S4 (continued 1) Characterization of the lake complexes from Danube Delta based on their biological and hydro-geomorphological features

\begin{tabular}{|c|c|c|c|c|c|c|}
\hline $\begin{array}{c}\text { Lakes } \\
\text { complex * } \\
(\mathrm{W} \rightarrow \mathrm{E}) \\
\end{array}$ & $\begin{array}{c}\text { Lake } \\
\text { name and code }\end{array}$ & $\begin{array}{c}\text { Water } \\
\text { retention } \\
\text { (weeks) }\end{array}$ & $\begin{array}{c}\text { Water } \\
\text { velocity** } \\
(\mathbf{m} / \mathbf{s}) \\
\end{array}$ & $\begin{array}{c}\text { Floating } \\
\text { macrophyte }{ }^{* *} \\
\text { (average coverage units) }\end{array}$ & $\begin{array}{c}\text { Submerse } \\
\text { macrophyte } * * \\
\text { (average coverage units) }\end{array}$ & $\begin{array}{c}\text { Total } \\
\text { macrophyte** } \\
\text { (average coverage units) }\end{array}$ \\
\hline \multirow{4}{*}{$\begin{array}{l}\text { Isac-Gorgova } \\
\text { (LC2) }\end{array}$} & Isac (IS) & $4-6$ & 0.07 & 12.5 & 35.6 & 48.1 \\
\hline & Uzlina (UZ) & $4-6$ & 0.08 & 35.8 & 35.8 & 71.6 \\
\hline & Cuibul cu Lebede (CL) & $<2$ & 0.08 & 35.4 & 35.3 & 70.7 \\
\hline & Gorgostel (GR) & $4-6$ & 0.07 & 36 & 35.9 & 71.9 \\
\hline \multirow{10}{*}{$\begin{array}{l}\text { Matița-Merhei } \\
\text { (LC3) }\end{array}$} & Trei Iezere (TI) & $<2$ & 0.07 & 35 & 35 & 70 \\
\hline & La Amiază (LA) & $<2$ & 0.06 & 35.2 & 35.2 & 70.4 \\
\hline & Bogdaproste (BG) & $<2$ & 0.07 & 35.2 & 35.3 & 70.5 \\
\hline & Matița (MA) & $<2$ & 0.11 & 12.5 & 12.5 & 25 \\
\hline & Merhei (ME) & $<2$ & 0.13 & 12.5 & 35 & 47.5 \\
\hline & Merhei Mic (MM) & $<2$ & 0.09 & 34.9 & 34.8 & 69.7 \\
\hline & Lung (LU) & $<2$ & 0.07 & 34.7 & 34.9 & 69.6 \\
\hline & Dracului (DR) & $<2$ & 0.10 & 12.5 & 35 & 47.5 \\
\hline & Rădăcinoasele (RE) & $<2$ & 0.08 & 12.5 & 35 & 47.5 \\
\hline & Babina (BA) & $<2$ & 0.10 & 12.5 & 35 & 47.5 \\
\hline \multirow{5}{*}{$\begin{array}{l}\text { Roșu-Puiu } \\
\text { (LC4) }\end{array}$} & Roșu (RO) & $2-4$ & 0.14 & 12.5 & 36.3 & 48.8 \\
\hline & Roșuleț (RT) & $2-4$ & 0.11 & 36.3 & 36.3 & 72.6 \\
\hline & Mândra (MD) & $2-4$ & 0.11 & 12.5 & 36.3 & 48.8 \\
\hline & Puiu (PU) & $2-4$ & 0.11 & 12.5 & 12.5 & 25 \\
\hline & Erenciuc (ER) & $>4$ & 0.09 & 37.5 & 36 & 73.5 \\
\hline
\end{tabular}

*lakes complex Șontea-Furtuna (LC1), part of the fluvial delta, was not included in this study

**this study; measurements were done using GoogleEarthPro software

***DDNIRD = Danube Delta National Institute for Research and Development

****bolded characteristics were included in hydro-geomorphologycal analyses as well

\#for each category a number from 1 to 6 was atributed for statistical analyses 
Table S4 (continued 2) Characterization of the lake complexes from Danube Delta based on their biological and hydro-geomorphological features

\begin{tabular}{|c|c|c|c|c|c|c|}
\hline $\begin{array}{c}\text { Lakes complex } \\
* \\
(\mathrm{~W} \rightarrow \mathrm{E})\end{array}$ & $\begin{array}{c}\text { Lake } \\
\text { name and code }\end{array}$ & $\begin{array}{c}\text { Lake bottom } \\
\text { type }^{8}\end{array}$ & $\begin{array}{c}\text { Thickness of peat } \\
\text { deposits }^{8} \\
(\mathrm{~cm})\end{array}$ & $\begin{array}{c}\text { Reed beds } \\
\text { presence }^{* *},\end{array}$ & $\begin{array}{c}\text { Phytoplankton } \\
\text { diversity }^{\#, 9}\end{array}$ & $\begin{array}{c}\text { Water birds } \\
\text { colonies } \\
\text { presence }^{\#, 10}\end{array}$ \\
\hline \multirow{4}{*}{$\begin{array}{l}\text { Isac-Gorgova } \\
\text { (LC2) }\end{array}$} & Isac (IS) & mineral & $50-130$ & high & low & \multirow{4}{*}{ medium } \\
\hline & Uzlina (UZ) & organic & $20-50$ & medium & medium & \\
\hline & Cuibul cu Lebede (CL) & organic & $20-50$ & high & high & \\
\hline & Gorgostel (GR) & mineral & $20-50$ & high & high & \\
\hline \multirow{10}{*}{$\begin{array}{l}\text { Matița-Merhei } \\
\text { (LC3) }\end{array}$} & Trei Iezere (TI) & organic & $20-50$ & high & medium & \multirow{10}{*}{ high } \\
\hline & La Amiază (LA) & organic & $20-50$ & high & high & \\
\hline & Bogdaproste (BG) & organic & $20-50$ & high & medium & \\
\hline & Matița (MA) & mineral & $130-200$ & high & low & \\
\hline & Merhei (ME) & organic & $20-50$ & high & low & \\
\hline & Merhei Mic (MM) & organic & $50-130$ & high & low & \\
\hline & Lung (LU) & organic & $50-130$ & high & high & \\
\hline & Dracului (DR) & organic & $20-50$ & high & medium & \\
\hline & Rădăcinoasele (RE) & organic & $20-50$ & high & high & \\
\hline & Babina (BA) & mineral & $20-50$ & high & medium & \\
\hline \multirow{5}{*}{$\begin{array}{l}\text { Roșu-Puiu } \\
\text { (LC4) }\end{array}$} & Roșu (RO) & mineral & $130-200$ & high & low & \multirow{5}{*}{ low } \\
\hline & Roșuleț (RT) & mineral & $50-130$ & very high & low & \\
\hline & Mândra (MD) & organic & $20-50$ & medium & low & \\
\hline & Puiu (PU) & mineral & $130-200$ & high & low & \\
\hline & Erenciuc (ER) & organic & $20-50$ & high & high & \\
\hline
\end{tabular}

*lakes complex Șontea-Furtuna (LC1), part of the fluvial delta, was not included in this study

**this study; measurements were done using GoogleEarthPro software

***DDNIRD = Danube Delta National Institute for Research and Development

$* * * *$ bolded characteristics were included in hydro-geomorphologycal analyses as well

\#for each category a number from 1 to 6 was atributed for statistical analyses 


\section{Table S4 References}

1. Gâştescu, P., Ştiucă, R., 2008. Delta Dunării - Rezervaţie a Biosferei. Petre Gâştescu and Romulus Ştiucă (eds) Bucureşti: CD PRESS, 400 pp. ISBN 978-973-1760-98-9.

2. Mierlă, M., Romanescu, G., Nichersu, I. and Grigoraș, I., 2014. Hydrological risk map for the Danube delta—a case study of floods within the fluvial delta. IEEE Journal of Selected Topics in Applied Earth Observations and Remote Sensing, 8(1), pp.98-104.

3. Niculescu, S., Guttler, F.N., Lardeux, C. and Rudant, J.P., 2008, November. Multisensor Systems and Floods Risk Management in the Danube Delta. In ALOS PI 2008 Symposium (Vol. 664).

4. Doroftei, M., Mierlă, M. and Lupu, G., 2011. APPROACHES TO HABITAT DISTURBANCES IN THE DANUBE DELTA BIOSPHERE RESERVE. SCSB Veg. Biol, 20(1), pp.45-56.

5. Cioacă, E., Bondar, C., Borcia, C., Mierlă, M., Ince, A., Hydraulic model to assess the hydromorphological changes within the Danube Delta, Scientific Annals of the Danube Delta Institute Tulcea, Romania, vol. 18 2012, pp. 303 - 310 doi: 10.7427/DDI.18.21

6. Oosterberg, W., Buijse, A.D., Coops, H., Ibelings, B.W. and Menting, G.A.M., 2000. Ecological gradients in the Danube Delta lakes: present state and man-induced changes. Ministry of Transport, Public Works and Water Management.

7. Friedrich, J., Dinkel, C., Grieder, E., Radan, S., Secrieru, D., Steingruber, S. and Wehrli, B., 2003. Nutrient uptake and benthic regeneration in Danube Delta Lakes. Biogeochemistry, 64(3), pp.373-398.

8. Munteanu, I., 1996. Soils of the Romanian Danube Delta Biosphere Reserve. Ministry of Transport, Public Works and Water Management, Directorate-General of Public Works and Water Management, Institute for Inland Water Management and Waste Water Treatment, RIZA.

9. Török, L., 2005. Ecological status of the Danube Delta Biosphere Reserve's Lakes. Scientific Annals of the Danube Delta Institute for Research and Development, TulceaRomania: 112-115.

10. Marinov, M., Doroșencu, A., Alexe, V., Bolboacă, L.E., Botond, J., Kiss, C.N., Tosic, K. and Tudor, M., Assessment of colonial waterbirds in the Danube Delta Biosfere reserve (Romania) during 2015-2018. In their articles presented, in oral or poster sessions, during the GLOREP 2018 conference, organized in Timisoara, Romania, by 1517th November, 2018, under the auspices of the Balkan Environmental (p. 155). 
Table S5 Regression analysis using Spearman multiple correlation nonparametric for the 19 lakes describing variables (bolded and in orange color are variables strongly correlated)

\begin{tabular}{|c|c|c|c|c|c|c|c|c|c|c|c|c|c|c|c|c|c|c|c|}
\hline Variables* & kmp & shore & elev & medist & connect & depth & macroflo & macrosub & macrotot & peat & reed & retention & phpdiv & trans_m & trans_p & floodrisk & turb & waterflo & watervelo \\
\hline kmp & 1 & 0.62 & 0.38 & -0.25 & 0.62 & 0.5 & -0.45 & -0.08 & -0.44 & 0.42 & 0.07 & 0.37 & -0.72 & 0.25 & -0.04 & 0.37 & 0.06 & 0.5 & 0.53 \\
\hline shore & 0.62 & 1 & 0.31 & 0.03 & 0.21 & 0.52 & -0.21 & -0.01 & -0.21 & 0.18 & 0.29 & 0.37 & -0.45 & 0.1 & -0.11 & 0.13 & 0.26 & 0.45 & 0.46 \\
\hline elev & 0.38 & 0.31 & 1 & 0.32 & 0.25 & 0.26 & -0.64 & -0.07 & -0.57 & 0.15 & -0.24 & 0.12 & -0.59 & -0.17 & -0.24 & 0 & 0.09 & 0.48 & 0.54 \\
\hline medist & -0.25 & 0.03 & 0.32 & 1 & -0.53 & 0.2 & -0.32 & -0.37 & -0.42 & -0.07 & -0.09 & -0.14 & 0.11 & 0.05 & -0.28 & -0.11 & -0.05 & 0.31 & 0.32 \\
\hline connect & 0.62 & 0.21 & 0.25 & -0.53 & 1 & 0.38 & -0.11 & 0.22 & -0.07 & 0.27 & -0.12 & 0.1 & -0.47 & 0.01 & -0.25 & 0.13 & 0.18 & 0.2 & 0.23 \\
\hline depth & 0.5 & 0.52 & 0.26 & 0.2 & 0.38 & 1 & -0.22 & 0.22 & -0.23 & 0.44 & 0.22 & 0.53 & -0.45 & 0.02 & -0.78 & -0.02 & 0.57 & 0.58 & 0.59 \\
\hline macroflo** & -0.45 & -0.21 & -0.64 & -0.32 & -0.11 & -0.22 & 1 & 0.43 & 0.95 & -0.3 & 0.17 & 0.12 & 0.48 & -0.05 & 0.12 & 0.12 & 0.28 & -0.35 & -0.44 \\
\hline macrosub & -0.08 & -0.01 & -0.07 & -0.37 & 0.22 & 0.22 & 0.43 & 1 & 0.63 & -0.25 & -0.11 & 0.6 & 0.04 & -0.23 & -0.34 & -0.05 & 0.56 & 0.04 & 0.03 \\
\hline macrotot & -0.44 & -0.21 & -0.57 & -0.42 & -0.07 & -0.23 & 0.95 & 0.63 & 1 & -0.34 & 0.08 & 0.22 & 0.43 & -0.11 & 0.1 & 0.11 & 0.33 & -0.35 & -0.42 \\
\hline peat & 0.42 & 0.18 & 0.15 & -0.07 & 0.27 & 0.44 & -0.3 & -0.25 & -0.34 & 1 & 0.33 & 0.17 & -0.59 & -0.26 & -0.42 & -0.09 & 0.11 & 0.36 & 0.38 \\
\hline reed & 0.07 & 0.29 & -0.24 & -0.09 & -0.12 & 0.22 & 0.17 & -0.11 & 0.08 & 0.33 & 1 & 0.03 & -0.02 & 0 & -0.09 & -0.22 & -0.01 & 0.13 & 0.04 \\
\hline retention & 0.37 & 0.37 & 0.12 & -0.14 & 0.1 & 0.53 & 0.12 & 0.6 & 0.22 & 0.17 & 0.03 & 1 & -0.4 & -0.13 & -0.37 & 0.24 & 0.62 & 0.43 & 0.44 \\
\hline phpdiv** & -0.72 & -0.45 & -0.59 & 0.11 & -0.47 & -0.45 & 0.48 & 0.04 & 0.43 & -0.59 & -0.02 & -0.4 & 1 & 0.05 & 0.21 & -0.12 & -0.06 & -0.63 & -0.67 \\
\hline trans_m** & 0.25 & 0.1 & -0.17 & 0.05 & 0.01 & 0.02 & -0.05 & -0.23 & -0.11 & -0.26 & 0 & -0.13 & 0.05 & 1 & 0.47 & 0.45 & -0.38 & -0.19 & -0.19 \\
\hline trans_p ${ }^{* * *}$ & -0.04 & -0.11 & -0.24 & -0.28 & -0.25 & -0.78 & 0.12 & -0.34 & 0.1 & -0.42 & -0.09 & -0.37 & 0.21 & 0.47 & 1 & 0.36 & -0.61 & -0.47 & -0.49 \\
\hline floodrisk & 0.37 & 0.13 & 0 & -0.11 & 0.13 & -0.02 & 0.12 & -0.05 & 0.11 & -0.09 & -0.22 & 0.24 & -0.12 & 0.45 & 0.36 & 1 & -0.01 & -0.08 & -0.04 \\
\hline turb $^{* * *}$ & 0.06 & 0.26 & 0.09 & -0.05 & 0.18 & 0.57 & 0.28 & 0.56 & 0.33 & 0.11 & -0.01 & 0.62 & -0.06 & -0.38 & -0.61 & -0.01 & 1 & 0.4 & 0.37 \\
\hline waterflo** & 0.5 & 0.45 & 0.48 & 0.31 & 0.2 & 0.58 & -0.35 & 0.04 & -0.35 & 0.36 & 0.13 & 0.43 & -0.63 & -0.19 & -0.47 & -0.08 & 0.4 & 1 & 0.98 \\
\hline watervelo & 0.53 & 0.46 & 0.54 & 0.32 & 0.23 & 0.59 & -0.44 & 0.03 & -0.42 & 0.38 & 0.04 & 0.44 & -0.67 & -0.19 & -0.49 & -0.04 & 0.37 & 0.98 & 1 \\
\hline
\end{tabular}

*kmp=surface $(\mathrm{kmp})$, shore=shore length $(\mathrm{km})$, elev=elevation $(\mathrm{m})$, mcdist=main channel distance $(\mathrm{km})$, connect=connectivity with the river branch Sulina $($ categories), depth=water level $(\mathrm{m})$,

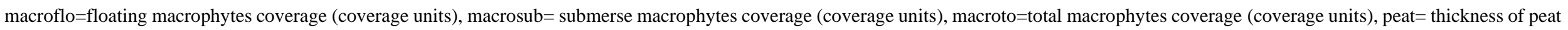

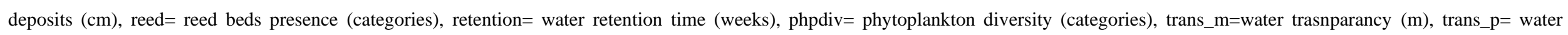
transparency (\% from water level), floodrisck=flooding risk (categories), turb=water turbidity $(\mathrm{NTF})$, waterflo= water flowing rate, watervelo=water velocity $(\mathrm{m} / \mathrm{s})$

**variables were not included in further tests either because there are considered both cause and effect (transparency) or because there are strongly correlated with other variables 


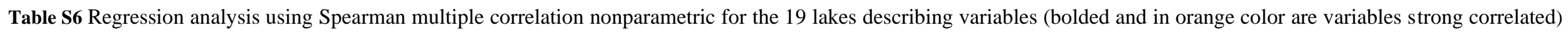

$-p$ values

\begin{tabular}{|c|c|c|c|c|c|c|c|c|c|c|c|c|c|c|c|c|c|c|c|}
\hline Variables* & kmp & shore & elev & mcdist & connect & depth & macroflo & macrosub & macrotot & peat & reed & retention & phpdiv & trans_m & trans_p & floodrisk & turb & waterflo & watervelo \\
\hline kmp & & 0.0048 & 0.11 & 0.3002 & 0.0044 & 0.0294 & 0.0532 & 0.7452 & 0.0617 & 0.0726 & 0.7656 & 0.1166 & 0.0005 & 0.3019 & 0.8866 & 0.1232 & 0.8028 & 0.0305 & 0.02 \\
\hline shore & 0.0048 & & 0.1923 & 0.9035 & 0.3788 & 0.0236 & 0.3889 & 0.9712 & 0.3885 & 0.451 & 0.2233 & 0.1196 & 0.0547 & 0.6896 & 0.6524 & 0.6067 & 0.2864 & 0.0557 & 0.0452 \\
\hline elev & 0.11 & 0.1923 & & 0.182 & 0.2937 & 0.2764 & 0.0033 & 0.771 & 0.0112 & 0.5376 & 0.3155 & 0.6143 & 0.0076 & 0.4786 & 0.3243 & 0.993 & 0.7 & 0.039 & 0.0179 \\
\hline medist & 0.3002 & 0.9035 & 0.182 & & 0.0209 & 0.4054 & 0.1815 & 0.1199 & 0.0763 & 0.7774 & 0.7103 & 0.5667 & 0.6526 & 0.8294 & 0.2537 & 0.6542 & 0.8529 & 0.1995 & 0.183 \\
\hline connect & 0.0044 & 0.3788 & 0.2937 & 0.0209 & & 0.1073 & 0.6444 & 0.3732 & 0.7806 & 0.2598 & 0.6168 & 0.698 & 0.0437 & 0.9682 & 0.296 & 0.6037 & 0.4732 & 0.4011 & 0.3491 \\
\hline depth & 0.0294 & 0.0236 & 0.2764 & 0.4054 & 0.1073 & & 0.3553 & 0.3631 & 0.3419 & 0.0566 & 0.3699 & 0.0183 & 0.0505 & 0.9368 & 0.000 & 0.9394 & 0.0113 & 0.009 & 0.0073 \\
\hline macroflo** & 0.0532 & 0.3889 & 0.0033 & 0.1815 & 0.6444 & 0.3553 & & 0.0692 & 0.000 & 0.2062 & 0.48 & 0.6125 & 0.0363 & 0.8419 & 0.6201 & 0.6149 & 0.2453 & 0.1476 & 0.0611 \\
\hline macrosub & 0.7452 & 0.9712 & 0.771 & 0.1199 & 0.3732 & 0.3631 & 0.0692 & & 0.0036 & 0.3078 & 0.6484 & 0.0067 & 0.8822 & 0.351 & 0.1569 & 0.8242 & 0.012 & 0.8824 & 0.8892 \\
\hline macrotot & 0.0617 & 0.3885 & 0.0112 & 0.0763 & 0.7806 & 0.3419 & 0.000 & 0.0036 & & 0.1563 & 0.7558 & 0.365 & 0.0661 & 0.6588 & 0.6822 & 0.661 & 0.1703 & 0.141 & 0.0715 \\
\hline peat & 0.0726 & 0.451 & 0.5376 & 0.7774 & 0.2598 & 0.0566 & 0.2062 & 0.3078 & 0.1563 & & 0.173 & 0.4906 & 0.0081 & 0.2826 & 0.0726 & 0.7134 & 0.6498 & 0.1349 & 0.1106 \\
\hline reed & 0.7656 & 0.2233 & 0.3155 & 0.7103 & 0.6168 & 0.3699 & 0.48 & 0.6484 & 0.7558 & 0.173 & & 0.9051 & 0.9403 & 0.9955 & 0.7145 & 0.3572 & 0.9686 & 0.6037 & 0.8617 \\
\hline retention & 0.1166 & 0.1196 & 0.6143 & 0.5667 & 0.698 & 0.0183 & 0.6125 & 0.0067 & 0.365 & 0.4906 & 0.9051 & & 0.0908 & 0.5883 & 0.1196 & 0.3316 & 0.005 & 0.0684 & 0.0598 \\
\hline phpdiv** & 0.0005 & 0.0547 & 0.0076 & 0.6526 & 0.0437 & 0.0505 & 0.0363 & 0.8822 & 0.0661 & 0.0081 & 0.9403 & 0.0908 & & 0.8375 & 0.3998 & 0.6102 & 0.7957 & 0.0037 & 0.0017 \\
\hline trans_m** & 0.3019 & 0.6896 & 0.4786 & 0.8294 & 0.9682 & 0.9368 & 0.8419 & 0.351 & 0.6588 & 0.2826 & 0.9955 & 0.5883 & 0.8375 & & 0.0428 & 0.0529 & 0.1105 & 0.4261 & 0.4275 \\
\hline trans_p $\mathbf{p}^{* * *}$ & 0.8866 & 0.6524 & 0.3243 & 0.2537 & 0.296 & 0.000 & 0.6201 & 0.1569 & 0.6822 & 0.0726 & 0.7145 & 0.1196 & 0.3998 & 0.0428 & & 0.1285 & 0.006 & 0.0425 & 0.0331 \\
\hline floodrisk & 0.1232 & 0.6067 & 0.993 & 0.6542 & 0.6037 & 0.9394 & 0.6149 & 0.8242 & 0.661 & 0.7134 & 0.3572 & 0.3316 & 0.6102 & 0.0529 & 0.1285 & & 0.9659 & 0.7349 & 0.8683 \\
\hline $\operatorname{turb}^{* *}$ & 0.8028 & 0.2864 & 0.7 & 0.8529 & 0.4732 & 0.0113 & 0.2453 & 0.012 & 0.1703 & 0.6498 & 0.9686 & 0.005 & 0.7957 & 0.1105 & 0.006 & 0.9659 & & 0.0935 & 0.1162 \\
\hline waterflo** & 0.0305 & 0.0557 & 0.039 & 0.1995 & 0.4011 & 0.009 & 0.1476 & 0.8824 & 0.141 & 0.1349 & 0.6037 & 0.0684 & 0.0037 & 0.4261 & 0.0425 & 0.7349 & 0.0935 & & 0.000 \\
\hline watervelo & 0.02 & 0.0452 & 0.0179 & 0.183 & 0.3491 & 0.0073 & 0.0611 & 0.8892 & 0.0715 & 0.1106 & 0.8617 & 0.0598 & 0.0017 & 0.4275 & 0.0331 & 0.8683 & 0.1162 & 0.000 & \\
\hline
\end{tabular}

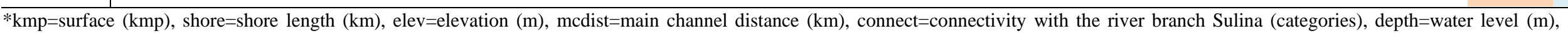

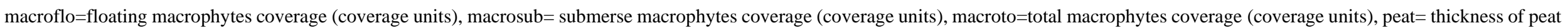

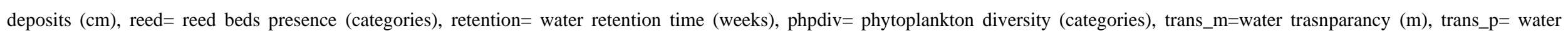
transparency (\% from water level), floodrisck=flooding risk (categories), turb=water turbidity $(\mathrm{NTF})$, waterflo= water flowing rate, watervelo=water velocity $(\mathrm{m} / \mathrm{s})$

**variables were not included in further tests either because there are considered both cause and effect (transparency) or because there are strongly correlated with other variables 


\section{Cyanobacteria biovolume}

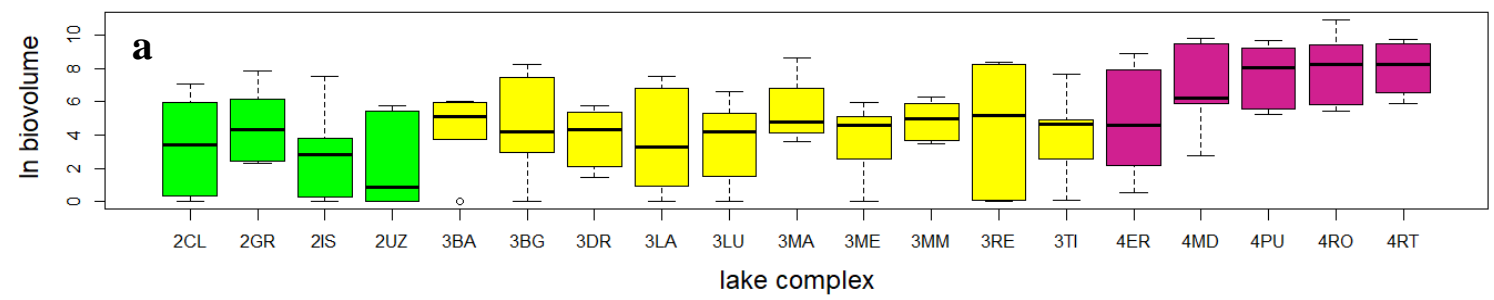

Cyanobacteria genus richness

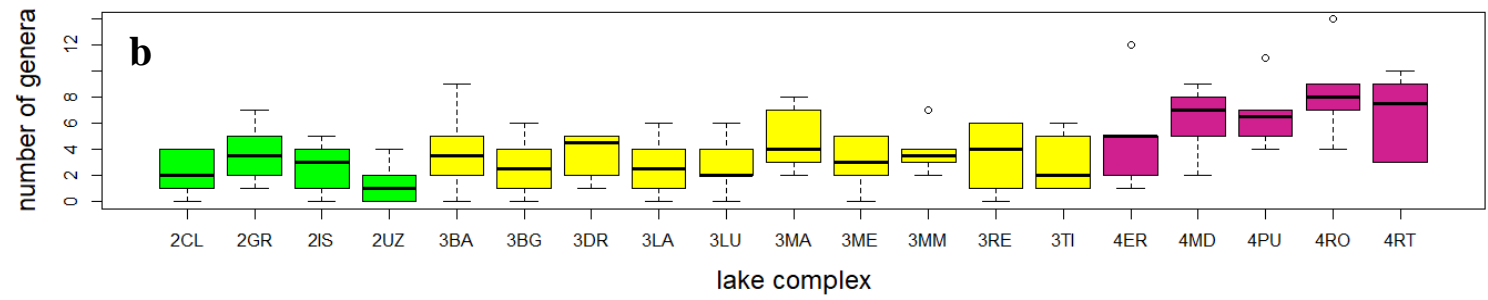

Fig. S1 Cyanobacteria biovolume (a) and genus richness (b) for every studied lake (displayed from West to East): Isac (IS), Uzlina (UZ), Cuibul cu Lebede (CL), Gorgostel (GR) part of Gorgova- Uzlina (LC2, green), Trei Iezere (TI), La Amiază (LA), Bogdaproste (BG), Matița (MA), Merhei (ME), Merhei Mic (MM), Lung (LU), Dracului (DR), Rădăcinoasele (RE), Babina (BA) part of Matița-Merhei (LC3, yellow) and Roșu (RO), Roșuleț (RT), Mândra (MD), Puiu (PU), Erenciuc (ER) part of Roșu-Puiu (LC4, purple)

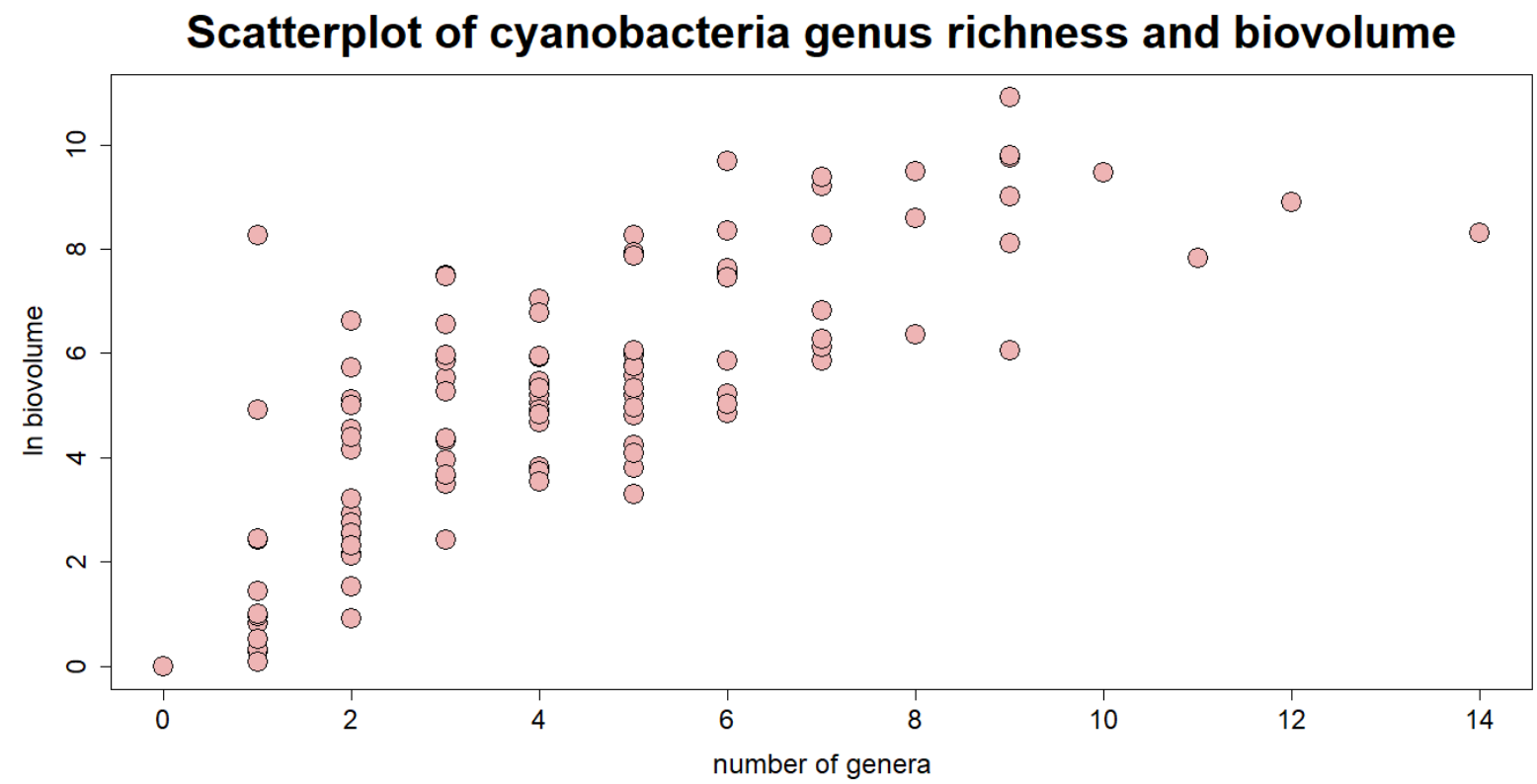

Fig. S2 Scatterplot of cyanobacteria genus richness and biovolume (ln value) in the Danube Delta lakes during the study period. The two parameters are significantly $(p<0.001)$ and positively and strongly correlated according to Pearson correlation coefficient $(\rho=0.819)$ 

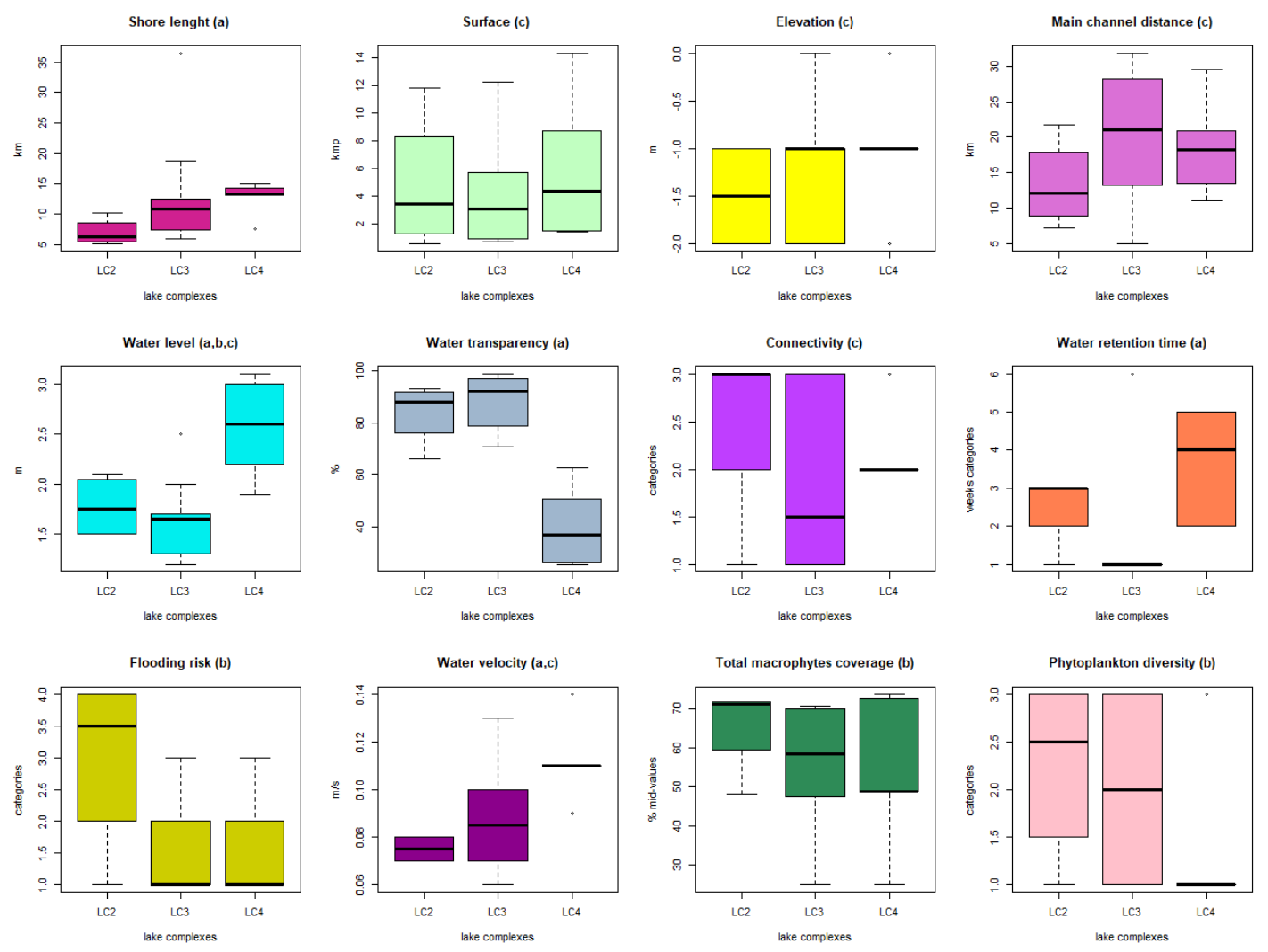

Fig. S3 Danube Delta lake parameters that significantly: (a) describe the lake complexes (LC2 = Gorgova- Uzlina, LC3=Matița-Merhei and LC4=Roșu-Puiu), (b) predict cyanobacteria biovolume and (c) cyanobacteria genus richness. The hydro-geomorphological features are described in Table S5

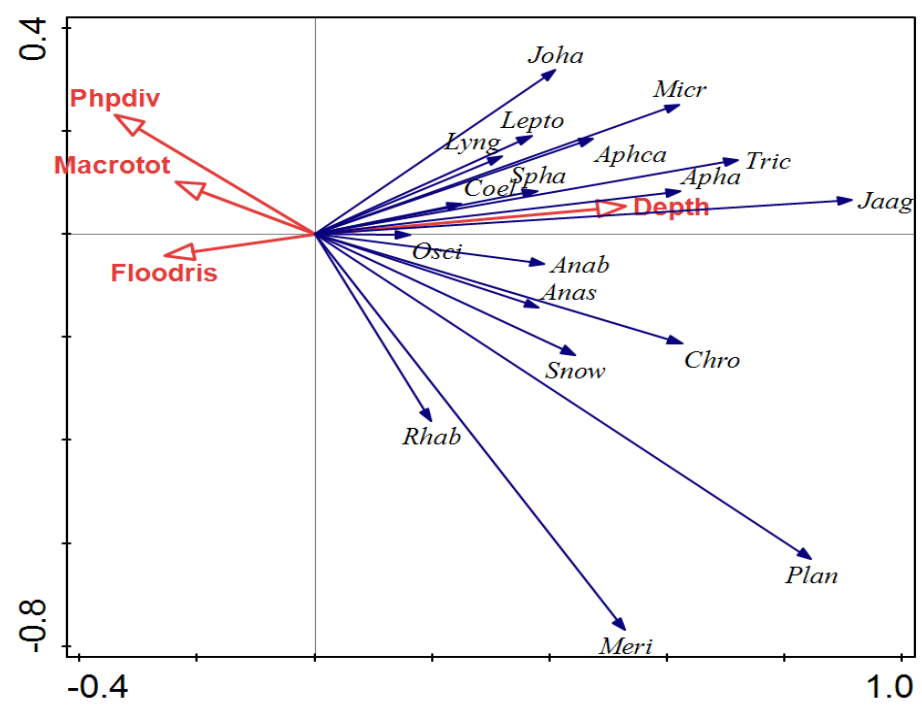

Fig. S4 Genera (in terms of biovolume) - lake characteristics biplot diagram from linear redundancy analysis (RDA) with lake complex as covariate. The codes for cyanobacteria genera are: Anabaena (Anab), Anabaenopsis (Anas), Aphanizomenon (Apha), Aphanocapsa (Aphca), Coelosphaerium (Coel), Chroococcus (Chro), Jaaginemoa (Jaag), Johanseninema (Joha), Lyngbya (Lyng), Leptolyngbya (Lepto), Microcystis (Micr), Merismopedia (Meri), Oscillatoria (Osci), Planktolyngbya (Plan), Rhabdogloea (Rhab), Snowella (Snow), Trichormus (Tric) and Wollea (Spha). Lake characteristics were: flooding risk (floodris), total macrophyte coverage water velocity (macrotot), water level (depth) and phytoplankton diversity (phpdiv). Genera with less than four occurences were not included in the analysis 